\title{
NOVEDAD Y PERFECCIÓN DEL PENSAMIENTO DE LOS PRÁCTICOS SOBRE LOS DELITOS EN PARTICULAR
}

\author{
Manuel María Zorrilla Ruiz
}

\begin{abstract}
Sumario: 1. Introducción. 2. Clasificación DE los Delitos. 3. Adulterio. 4. Asesinato. 5. Blasfemia. 6. Falsedad. 7. FornicaCión. 8. Hurto. 9. Crimen de herejía. 10. Homicidio. 11. InCESTO. 12. Injuria. 13. Lesa Majestad. 14. Juego. 15. Parricidio. 16. PerJuRio. 17. Rapto. 18. Sacrilegio. 19. Simonía. 20. Sodomía. 21. EstuPRO. 22. CONCLUSIONES. 23. BibliografíA DE ORIENTACIÓN.
\end{abstract}

\section{INTRODUCCION}

A lo largo del siglo XVI se va consolidando una etapa comprometida con la tendencia a difundir y relacionar las ideas generales inherentes a la recepción del Derecho Romano y el Derecho Canónico.

La incoación del proceso generalizador y expansivo de las categorías del Derecho Penal -reclamado por el carácter de la disciplina y sus imperativos básicos de racionalización- provoca consecuencias anejas al fenómeno de la recepción del Derecho Romano. Hasta que se reparó en la importancia de este punto de inflexión, la legislación condescendía y comulgaba con un estado caótico de cosas que se cancelará para reordenar un espacio -casuístico y efervescente- que, devaluando el Derecho punitivo, frenaba sus operaciones de aplicación y de progreso. La contribución -rigurosa y dogmática- de los prácticos que cerraron un ciclo de gran espesura, siguió a la de los glosadores y los postglosadores. Los primeros trataron de operar sobre las normas penales de la compilación justiniánea que, merced a su tradición y consistencia, postulaban su incorporación al Derecho vivo y razonable, sustituyendo al totum revolutum del Derecho punitivo de la Edad Media y de comienzos de la Edad Moderna. Los segundos, llamados también comentaristas, aprove- 
chan la labor de desbroce que los glosadores llevaron a cabo -liquidando la dispersión anárquica del Derecho anterior- y extienden su curiosidad constructiva y científica al Derecho Romano -objeto de la recepción- y a un Derecho común contemporáneo, cuya vigencia aportaba experiencias jurídicas susceptibles de maduración y detenido estudio. De ahí, la relevancia de la autoridad de los Doctores y su conversión en fuente del Derecho objetivo. El seguimiento de este itinerario infiltró criterios generales o enunciados de corte teorizante en el cuerpo de un Derecho Penal sucesivamente mejorado por los glosadores, los postglosadores y los prácticos.

Nada tan provechoso para obtener una perspectiva peculiar de este progreso, cómo advertir que los prácticos asumieron e introdujeron los avances incoados con la recepción romanocanónica y el apoyo de los glosadores y los comentaristas. JULIO CLARO de ALEJANDRIA -el más notable de esos pensadores, llamado a España por FELIPE II- se distinguió, de entrada, por abordar las cuestiones de Derecho Penal sobre la arquitectura legislativa del Estado de Milán, pero, además, llegó más lejos de esta indagación métodológica. No se contrajo al concienzudo examen de la misma y aportó una esmerada contribución teórica, fruto de sus fecundas experiencias, y una liberalidad de criterio fatigosamente asimilable en los tiempos que entonces le tocaba vivir.

La tentativa de situar su pensamiento merece algunas precisiones especiales. El conglomerado de fuentes del Derecho Penal comprendía el recurso al jus utriusque, el manejo del jus positum contenido en los statuta civitatis, el predicamento del principio de autoridad templado por condiciones morales y jurídicas, la influencia de la costumbre y el precedente constituido por el Derecho judicial. La atención dispensada a estas fuentes revela una oferta convincente, atractiva y completa, que es tanto como sistemática, seductora y exenta de lagunas.

La escasez, heterogeneidad y dispersión de los elementos interpretativos desnaturalizaban las reflexiones atinentes a la aplicación de la ley penal, a la desigualdad material de muchos de sus destinatarios, a los criterios sobre la personalidad del delincuente y a la responsabilidad penal de las personas morales.

La presentación y el examen de las ideas penales de Julio Claro de ALEJANDRIA se han obtenido a partir del texto de las Receptae sententiae, también denominadas Practica civilis y criminalis, cuya edición de Frankfurt (1.565), redactada en latín, abigarrada y exhaustiva, lleva a seleccionar, en lo posible, las posturas definidoras de los avances obtenidos. Merece el unánime elogio de haber superado los intereses forenses -que acampaban a ras de tierra- y facilitado innovaciones que transportaron al campo del Derecho Penal un sagaz espíritu crítico y un enriquecedor bagaje dogmático.

El análisis de los delitos en particular y la reordenación de sus contenidos se intenta, como sigue, respecto a las figuras que, según el subtítulo del texto 
analizado, aborda el todo de la materia criminal en cuanto a la persecución de los delitos y la defensa de los reos. Abarca, así las cosas, las figuras de adulterio, asesinato, blasfemia, falsedad, fornicación, hurto, herejía, homicidio, incesto, injuria, lesa majestad, juego, parricidio, perjurio, rapto, sacrilegio, simonía, sodomía y estupro. Los interrogantes de los respectivos capítulos esbozan los perfiles de un designio expansivo, ambicioso y densamente moralizador.

\section{CLASIFICACION DE LOS DELITOS}

Delitos públicos y privados.-Cualquier súbdito perteneciente a la comunidad o al pueblo puede emprender la acusación y la persecución de los primeros, que, entre otros, incluyen el crimen de lesa majestad, el adulterio, el homicidio, el parricidio, el peculado y el falso testimonio.

Ofensas a DIOS.-El delito directamente encaminado a ofender a DIOS se considera público y cualquier súbdito puede denunciar su comisión. Ofendiendo a DIOS se ofende a todos, porque -si se repara en la blasfemia, la destrucción de imágenes e iglesias y otras acciones semejantes- DIOS es el Padre y Señor de las mismas.

Ofensas al Soberano.-También es público el delito cuya comisión ofende al Soberano, puesto por DIOS en su lugar como padre y señor de los súbditos, ya que la ofensa hecha al primero se extiende a todos los demás.

División de opiniones.-Ante la duda de si es delito público la falsificación de un instrumento distinto del testamento, hay una minoría que lo niega y una notable mayoría que opina lo contrario.

Delitos privados.-Los delitos privados -como el hurto, los daños, las injurias, las talas furtivas de arbolado y la sustracción de bienes ajenos- sólo se pueden acusar y perseguir por la parte contra cuyos intereses atentan. La distinción es importante, pues la pena de infamia alcanza únicamente a los condenados por un delito público.

Normas rectoras.-Las distinciones se atienen a las reglas del Derecho común secular o civil, pero no a las del Derecho Canónico, que ignoran la figura de los delitos privados y disponen que todos los delitos son públicos. Cabe entonces proceder de oficio para perseguir los delitos privados y castigarlos con pena extraordinaria. Los estatutos y las costumbres locales fijan los criterios que, separando los delitos públicos de los delitos privados, inspiran y dan lugar a la represión correspondiente.

Enjuiciamiento de los delitos.-Los delitos pueden ser meramente eclesiásticos, meramente seculares o comunes. El conocimiento de los primeros -que incluye los crímenes de simonía y herejía- se reserva a los jueces eclesiásticos, aunque hayan sido laicos sus autores. De los delitos meramente seculares -como el homicidio, el hurto y otros semejantes- conocen los jueces seculares si sus autores son laicos. Los delitos se denominan comunes si, 
siendo laicos sus autores, conoce de ellos indistintamente un juez eclesiástico o un juez secular, como ocurre con el adulterio, el concubinato y la sodomía.

Delitos nominados.-Los delitos nominados gozan de una rotulación especial y constituyen un término atribuido por la ley. Sucede así cuando el apoderamiento de la cosa ajena determina la asignación legal de un nombre propio al delito de hurto o la relación de la mujer casada con un tercero da lugar a la descripción legal del adulterio.

Delitos innominados.-Los delitos innominados carecen de una rotulación jurídica concreta y de hecho se consideran tales cuando - como el incendio, la entrada en casa ajena y semejantes- sirven al designio de causar un mal. Sólo son punibles si ha precedido esa intención perversa. Los delitos nominados no pueden cometerse sin que medie la intención maliciosa y concreta de perjudicar que, caracteriza, por ejemplo, al adulterio, el hurto y el rapto.

Gravedad de los delitos.-Hay delitos leves, delitos graves o atroces y delitos muy atroces. Se echa en falta un criterio diferenciador, pues, mientras unos arguyen que las calificaciones respectivas dependen del arbitrio judicial, sostienen otros que el delito es tanto más grave, cuanto más grave sea la pena con que se le sanciona. Son delitos atroces la rebelión, el crimen de lesa majestad, el homicidio causado de propósito, la falsificación de moneda, el tercer homicidio cometido por quien antes ha perpetrado otros dos homicidios, aunque no se le haya condenado por ellos, las lesiones causadas a traición, aunque la víctima no haya fallecido, el tercer hurto o la disminución de la moneda, el rapto de una virgen hija de padres honestos, aunque no haya cópula carnal, el trato carnal con virgen consagrada y residente en un monasterio, la sodomía, la cualidad de ladrón famoso, la falsificación del sello del Senado o del Príncipe. También son delitos atroces aquellos a los que la ley o el estatuto asignan pena de muerte natural o civil -como la condena perpetua a galeras- aplicada según los jueces la imponen y ejecutan. Más atroces o muy atroces son los delitos que las leyes o los estatutos castigan con pena de muerte más deshonrosa que la común, ordenando que los reos sean quemados, despedazados o atados a la cola de un caballo, si se trata de herejes, parricidas, asesinos, ladrones en las vías públicas, sodomitas, incendiarios y falsificadores de moneda. De igual naturaleza participan los delitos en que, como el crimen de lesa majestad, la pena de muerte se extiende a los hijos de los delincuentes. Lo mismo sucede si se establecen penas especiales para los raptores de vírgenes o mujeres honestas. La importancia de la diferencia es máxima, porque la ley permite a los jueces transgredir el Derecho cuando lo exijan la justicia y la enormidad de la infracción. Tratándose de delitos enormes y crímenes muy atroces, la posibilidad no sólo alcanza a los aspectos peculiares de la imposición de la pena, sino también a su ejecución o cumplimiento. Cabe acudir a la tortura, aunque no haya suficientes indicios ni se disponga de las actuaciones del proceso en que ha recaído la sentencia. 
Delitos de acción y de omisión.-De acuerdo con un principio general y asumido por todos, los delitos cometidos por acción se consideran más graves que los que consisten en abstenciones u omisiones.

Delitos de palabra.-Se pregunta si constituyen maleficio los delitos cometidos de palabra, a saber, las blasfemias, las injurias verbales y otros que se les asemejan. La posición negativa se funda en que, si hay maleficio allí donde se causa un mal, no cabe hablar de tal si se trata de maldiciones o escritos redactados con este carácter. La opinión contraria defiende que incluso hay maleficio si se delinque de palabra, porque, además de hacer mal quien maldice, también hace mal quien mal piensa y cuyo pensamiento merece un castigo.

Efectos de la contumacia.-No es, por si sola contumacia la incomparecencia del reo a quien se atribuye la comisión del delito de que se le acusa. Es válida la condena de aquél a quien se impone la pena después haber comparecido y formulado sus alegaciones defensivas frente a la acusación de un delito concreto, pero no incurre en contumacia quien, estando ausente y sin haber comparecido ante el juez, es condenado por el delito que se le reprocha. Puede declararse contumaz a quien no se condena por su incomparecencia y sí por la comisión de un delito cuya prueba plena se infiere de la contumacia. La contumacia constituye delito si entraña desprecio para con el juez ante quien debe comparecer el reo.

\section{ADULTERIO}

Acusación por adulterio.-Hay tres modos de formular la acusación por adulterio. El marido puede acusar a la mujer del adulterio cometido con otro varón. La mujer puede acusar al marido del adulterio cometido con otra mujer. El marido puede acusar conjuntamente a la mujer y al adúltero. La mujer puede solicitar la separación de lecho.

Variantes de la comisión del adulterio.-Son distintos los modos de incurrir en delito de adulterio. El adulterio cometido por un varón y una mujer casados se denomina así porque ambos violan el lecho propio y el ajeno. También hay adulterio entre un varón casado y una mujer soltera. Igualmente el adulterio surge cuando un varón soltero mantiene relación carnal con una mujer casada. Aunque el varón no esté casado, comete adulterio, porque viola el lecho ajeno, y la mujer se considera adúltera si viola el lecho propio, aunque no esté casado el varón con el que yace. Si el hombre casado cohabita con mujer soltera, el Derecho Civil entiende que no hay adulterio ni cabe imponer la pena establecida para los adúlteros, aunque el varón sea condenado por estupro. El Derecho Canónico estima que hay adulterio siempre que un varón o una mujer casados cohabiten con persona distinta de su cónyuge. A la tesis de que peca más gravemente que el presbítero, el laico casado que, al cometer adulterio, conoce carnalmente a otra mujer y viola el lecho de su 
cónyuge, se responde que el sacramento del orden sacerdotal no es menos respetable que el del matrimonio.

Adulterio de una mujer pública.-Si una mujer pública contrae matrimonio y, abandonando su anterior oficio, convive honestamente con su cónyuge, es punible el adulterio que un tercero comete con ella. Si, tras haber contraído matrimonio, persiste en su antiguo género de vida, no se puede imponer castigo alguno al varón con quien ha cohabitado.

Naturaleza del delito.-El adulterio constituye un delito privado que sólo puede perseguirse a instancia de personas determinadas.

Culpa lata.-La culpa lata se equipara al dolo en caso de adulterio.

Fuero del adulterio.-El delito de adulterio es de fuero común y pueden conocer del mismo los jueces seculares y los jueces eclesiásticos.

Penalidad del adulterio.-El Derecho Divino y la ley mosaica castigaban con la pena de muerte, por lapidación, el adulterio de la mujer y del varón. El Derecho Canónico establece que, si el marido no quiere restablecer la convivencia, se recluya a la mujer en un monasterio, donde hará penitencia de por vida. Es éste uno de los casos en que el Obispo puede sancionar a los laicos. El clérigo condenado por adulterio es privado de su condición de tal y recluido a perpetuidad en un monasterio, aunque el cumplimiento infrecuente de la pena demuestre que, en caso de aplicarse con mínimo rigor, pocos clérigos circularían por los caminos públicos. El Derecho Civil castiga el adulterio con la pena de deportación y no con la pena de muerte.

Moderación de la pena.-Debido a la fragilidad del sexo, la pena impuesta a la mujer adúltera se conmuta por la de reclusión en un monasterio donde ha de tomar el hábito y morar de por vida, si, en el plazo de dos años, el marido no la llama a su lado. El trato se suaviza si la mujer adúltera es condenada a la pena de azotes y destierro. Aunque algunos defienden la imposición al varón de la pena del último suplicio, se han generalizado la supresión de la pena de muerte por adulterio del varón y su sustitución por una pena pecuniaria. Es lamentable que los varones que comparecen ante los Tribunales eludan la pena del adulterio y se jacten de su comisión, hasta el punto de que las mujeres de los adúlteros no se atrevan a formular acusación para evitar la nota de infamia. Pecan gravísimamente los soberanos que no castigan el adulterio con penas muy severas o se abstienen de urgir su cumplimiento.

Efectos de los esponsales.-Se comete delito de adulterio cuando se yace con mujer desposada por palabras de presente, aunque no haya conocido varón, pero no, si los esponsales se han contraído por palabras de futuro.

Interferencias.-Al judío que comete adulterio con mujer cristiana en una ciudad donde el delito sólo se castiga con pena pecuniaria, no se le aplica la pena de muerte y sí la pena estatutaria que sustituye a la prevista por el Derecho Común. Si el judío comete adulterio con mujer cristiana, todavía soltera, o mujer pública, la duplicidad delictiva se castiga más severamente que lo dispuesto en la ley y apareja la condena a galeras a perpetuidad. 
Continuidad del adulterio.-El varón que mantiene repetidas y sucesivas relaciones carnales con la mujer de otro, comete otros tantos adulterios, aunque sólo se le imponga la pena asignada a un único delito.

Excusa absolutoria.-El padre de la mujer puede matar impunemente al adúltero sorprendido en el acto de la relación carnal con su hija.

Efectos patrimoniales.-En caso de adulterio de la mujer casada, el Derecho Canónico permite al varón solicitar la separación de lecho, pero no le autoriza a pedir la restitución de la dote ni de las donaciones por razón del matrimonio. Es tanta la inmanencia de este crimen, que, aunque el Derecho Divino prohibe al hombre separar lo que DIOS ha unido, el adulterio se reconoce excepcionalmente como causa de separación. Si el adulterio de la mujer es notorio, el marido puede expulsarla sin sentencia previa ni decisión episcopal. Si el matrimonio se separa a causa del adulterio del varón, éste devolverá a la mujer la dote recibida. Si la separación se debe al adulterio de la mujer, ésta pierde la dote y no puede exigir que se le restituya. Cabe que un varón tome como esposa a una mujer que no puede casarse con él -a causa de la consanguinidad o de cualquier otro impedimento legítimo- y que después incurre en adulterio causante de la privación de la dote. Si posteriormente el matrimonio es anulado, la mujer no puede reclamar la dote, pues la declaración de nulidad impide pronunciarse sobre la existencia del adulterio. Ello es así, porque, al menos putativamente, el estado matrimonial ya existía al producirse el adulterio, sin que la declaración de nulidad excuse la intencionalidad de la mujer adúltera.

Otras consecuencias. - El adulterio de la mujer la priva de la dote y de los bienes parafernales. El adulterio del marido le priva de las donaciones por razón del matrimonio, de las que la mujer se beneficia. La mujer no sólo pierde la dote por causa de adulterio, sino también si realiza ciertos actos de preparación inmediata. Dado que el adulterio es muy difícil de probar y los besos constituyen esa preparación, se presume que la mujer es convicta de adulterio tan pronto como conste que ha besado a su amante. Este criterio impera en los órdenes civil y criminal.

Obligaciones del marido.-Producida la separación de lecho por adulterio de la mujer, el marido sigue obligado a alimentarla, pues, aunque adúltera, no deja de ser su esposa después de la separación. El marido debe permanecer casto $y$, si comete fornicación, tiene que reanudar la convivencia con su esposa, no sólo cuando lo acuerde el juez de oficio, sino también si la mujer lo solicita.

Remisión del adulterio.-Hay remisión o perdón del delito, si el marido conoce el adulterio de la mujer y sigue cohabitando con ella. Peca mortalmente el marido que, sin haber hecho penitencia previa, mantiene relación carnal con la mujer adúltera. Ambos casos de adulterio no abundan en la práctica.

Otras particularidades.-Otras cuestiones se refieren a la excepción de adulterio -que puede oponer la mujer privada de la dote en perjuicio de sus 
padres o hijos- o a la necesidad de que, para evitar la restitución, el marido accione previamente en causa criminal.

Prescripción del delito.-Aunque, por lo común, los crímenes no prescriben antes de haber transcurrido veinte años desde su comisión, la acusación por adulterio simple prescribe a los cinco años y la de adulterio con incesto se sujeta al plazo general de prescripción. Es imprescriptible la excepción de adulterio que opone el marido frente la mujer que pide la restitución de la dote.

\section{ASESINATO}

Concepto de asesino.-Comete delito de asesinato el que ordena a un tercero, cristiano o infiel, que dé muerte a un cristiano. Con el tiempo, ha prevalecido la opinión de que no se trata de la conducta de ciertos hombres llamados asesinos, sino que sólo se considera tales a los que privan de la vida a un cristiano. Se presume cristiano a cualquier habitante del territorio cristiano, dada la gravedad de un delito que no admite distinciones sutiles. Sólo si el reo prueba que es infiel, se le absuelve del delito de asesinato.

Inclusión de los Obispos.-Esta disciplina incluye a los Obispos que, en su virtud, adquieren la condición de asesinos. El clérigo asesino puede ser condenado, previa degradación, por el juez secular.

Pena del asesinato.-El asesino es castigado con la pena de muerte y de arrastre atado a la cola de un caballo. Debe, además, ser despedazado, pues los jueces imponen esta pena a causa de la magnitud del crimen y para escarmiento de los súbditos.

Ausencia de inmunidad.-El asesino que se refugia en una iglesia no queda protegido por su inmunidad y puede ser desalojado de ella por decisión del juez secular.

Criterios de prueba.-Aunque la prueba del delito exija referencias más claras que la luz del día, la enormidad del asesinato autoriza a imponer una pena extraordinaria o condenar a una pena corporal aflictiva.

Punibilidad de la intención.-Aunque la intención de delinquir no es punible y la pena sólo se impone por el resultado, el propósito de asesinato se castiga, aunque el resultado no llegue a producirse. La doctrina es plausible y los jueces pueden aplicarla si consta en el Derecho común o en los estatutos. Se considera que delinque más quien, a cambio, recibe una suma de dinero, que quien lo hace gratuitamente.

\section{BLASFEMIA}

Concepto.-Constituye blasfemia todo insulto, contumelia o maldición proferida contra DIOS o los Santos. Varios dichos populares dan ejemplo de la comisión de este delito. La pena de blasfemia no se aplica a quien sólo manifiesta el deseo de que le ocurra un mal a otro. 
¿Delito atroz?-La expresión «pese a DIOS» no constituye blasfemia, si bien figura en el repertorio de los delitos atroces.

Pena de la blasfemia.-El Derecho Divino y las leyes mosaicas castigaban la blasfemia con la pena de muerte por lapidación. El Derecho Canónico obliga al blasfemo a hacer penitencia pública. El Derecho Civil establece la pena de muerte que, por paliativos de religión y de justicia, no suele imponerse, salvo si las blasfemias se profieren con ánimo maligno y execrable. Pecan muy gravemente los Príncipes y Magistrados cristianos que, siguiendo la costumbre, dejan de castigar severísimamente estos delitos que, según los casos y lugares, merecen la amputación y perforación de la lengua, el exilio y la imposición de una pena arbitraria.

Garantías del acusado.-Pese a la gravedad del delito de blasfemia, que lo es de lesa majestad divina, el acusado tiene derecho a demostrar que no ha delinquido y a desvirtuar las declaraciones de los testigos que avalan esta imputación. La blasfemia es un delito de fuero común que pueden perseguir los jueces eclesiásticos y los jueces civiles.

Competencia especial.-Los jueces seculares y no los eclesiásticos son competentes para castigar los delitos de blasfemia que cometen los judíos, salvo si la negligencia o la dilación de los primeros obliga a los segundos a encargarse de su represión.

Excusas y atenuantes.-El delito de blasfemia se excusa si se produce a impulsos de la ira y se castiga más benévolamente que si se comete en situaciones de embriaguez o de lascivia.

Otras moderaciones. - La costumbre provincial admite que, sin dejar de castigarse, el delito de blasfemia no lo sea con la pena ordinaria generalmente prevista para los blasfemos, pues abundan las expresiones de apariencia blasfema que, a diario, se profieren sin ánimo de delinquir.

\section{FALSEDAD}

Concepto de la falsedad.-La falsedad es un crimen gravísimo, de carácter público, que cualquiera puede denunciar respecto a documentos, declaraciones de testigos, escrituras y alteración de la moneda.

Falsedad testifical.-La presencia o ausencia del falso testimonio o falsedad cometida por medio de testigos, se contempla y debate en los casos de soborno de los mismos, preparación o propuesta de las declaraciones anteriores al juicio, especies de contradicciones testificales, acuerdos previos para reducirlas, referencias a los hechos extrínsecos o periféricos, declaraciones emitidas sin juramento previo y procedentes de testigos corruptos.

Falsedades documentales.-Las falsedades documentales emergen a causa de producción o el uso de documentos elaborado por un Notario público, del aprovechamiento intencional de las anomalías o contradicciones que puede registrar su contenido y de ciertos abusos de las libertades de contratar y testar. 
Especies de la falsedad.-Se castiga como homicida y, en vez de la deportación caída en desuso, se impone una pena pecuniaria al testigo que falta a la verdad en juicio y declara dolosamente contra un inocente. La falsedad no existe si el testigo declara en juicio lo contrario de lo manifestado antes del mismo, aunque sea punible omitir la verdad acerca de otros hechos intrínsecos. También comete falsedad el que usa de documentos que han sido declarados falsos.

Variantes de falsedad notarial.-Las especies de falsedad notarial pueden afectar a la producción material del testamento, a las magnitudes de diversa naturaleza reseñadas en el, a las sustituciones de personas ausentes, a documentos de contenido ilícito, a la negativa a otorgar un testamento, a la producción de instrumentos del Soberano y a la suposición de partos.

Falso testimonio.-Comete falsedad el que presenta en juicio testigos falsos e incurre en falso testimonio, castigado como homicidio, si deliberadamente se presta contra un inocente. No así, si se declara en su favor. El inocente que declara lo contrario de lo afirmado o negado antes del proceso, no incurre en falsedad, al contrario de si se contradice sobre las afirmaciones vertidas en el mismo juicio.

Excusa de la falsedad.-Queda excusado de la falsedad aquél cuya actitud o testimonio carece de intención dolosa, contribuye al prevalecimiento de la verdad o introduce alteraciones que a nadie perjudican.

Verificación de la falsedad material.-Los jueces deben examinar con detención el documento que permita conocer la verdad histórica allí donde, a primera vista cunde la impresión de haberse incurrido en falsedad. No debe olvidarse que, en materia penal, hay que individualizar el rigor de la presunción de falsedad, que sólo equivale a una sospecha necesitada de robustecerse y completarse con otros indicios y pruebas convincentes. Idea conexa con la regla de que la existencia del delito de falsedad requiere la mediación de dolo y que no cabe cometerlo por culpa o negligencia.

Modos de falsificación de moneda.-Los modos de falsificación de la moneda incluyen la fabricación material de sus unidades o piezas, las operaciones de adulteración, la reducción de su valor y la expendición de moneda ya falsificada.

\section{FORNICACIÓN}

Ámbito de la fornicación.-El Derecho Civil no prohíbe la fornicación simple entre un varón y mujer solteros, ni la fornicación concubinaria entre un varón casado y una mujer soltera, ni la relación con una mujer pública. El Derecho Canónico castiga la relación carnal y el coito extramatrimonial. El Derecho Divino y las leyes mosaicas prohíben la fornicación simple y la declaran pecado mortal. 
Castigo de la fornicación simple.-Entre la división de opiniones sobre si el clérigo que comete fornicación simple ha de ser castigado con la pena de deposición o la de simple suspensión, domina el parecer de que, ante la enormidad de la fornicación, debe imponerse la primera de ambas.

Relación especial.-El coito de un clérigo con mujer soltera no constituye sacrilegio ni incesto, sino fornicación simple, como la que puede cometer cualquier laico. El clérigo notoriamente fornicador queda de pleno Derecho suspendido en su oficio.

Supuestos condenables.-Se considera condenable el coito castigado por una ley humana y exterior. Son, según ello, coitos punibles los cometidos con concubina, con mujer virgen, con niña que no es capaz de recibir varón, con niño, con mujer casada, con viuda, con pariente afín, con monja, con presbítero, con dueña, con súbdita, con pupila, con mujer encarcelada, con judíos o infieles, con animales brutos, con mujer muerta y entre mujeres.

Prohibición del coito extramatrimonial.-El Derecho Canónico prohíbe el coito realizado fuera del matrimonio. El Derecho Civil entiende que el coito con la concubina no esta prohibido, pues sus normas no reprueban el concubinato dentro del que aquél puede cometerse, como lo acredita la costumbre que constituye la óptima interprete de la ley. El Derecho Canónico dispone que el laico que tiene concubina sufra la pena impuesta por el juez. El clérigo concubinario queda destituido de sus eventuales beneficios y obligado a devolver los frutos percibidos. Al varón relacionado con dos concubinas o una concubina y una esposa, se le imponía la pena de infamia, como si tuviese a la vez dos mujeres, si bien este criterio ha caído en desuso.

Conversión del concubinato.-La existencia del delito de concubinato exige unas condiciones que, si no se dan, convierten el crimen en estupro.

Fornicación de la mujer con presbítero.-Se prohibe la fornicación de la mujer con un presbítero, aunque no incurre en sacrilegio la concubina o la mujer soltera que se relaciona con él. El coito de un clérigo con mujer soltera no se considera adulterio, incesto o estupro, sino simple fornicación.

Coitos serviles.-El coito del siervo con su dueña constituye fornicación castigada con la pena de hoguera. El coito de la mujer con su siervo apareja la decapitación de la primera y la muerte del segundo en la hoguera. Se castiga también el coito cometido por el señor con una súbdita dentro del territorio del primero o el del oficial con mujer que de él dependa. Cometen fornicación los tutores o curadores que realizan el coito con la pupila durante la tutela o después de la misma. Es gravemente punible el coito que realiza con la mujer encarcelada, el varón encargado de custodiarla. Aunque el coito con una mujer pública no es punible, incluso si interviene la fuerza, el habido con mujer pública encarcelada se castiga a causa de las circunstancias de la custodia y del lugar en que se produce. No hay fornicación si un varón encarcelado cohabita con una mujer pública privada también de libertad. 
Fornicación con judíos.-Son punibles el coito de un varón judío con mujer cristiana o el de un cristiano con mujer hebrea. En el primer caso, no se impone la máxima pena y sí otras menos graves, aunque sea pública la mujer cristiana con la que el judío ha cohabitado. Ha de tratarse de una fornicación simple, porque, si se ha incurrido en adulterio, no hay razón para mejorar la suerte del judío respecto a la del cristiano castigado entonces con la pena de muerte.

Coito con animales brutos.-Constituye este coito un delito nefando que vulnera la naturaleza del género humano y que, al uso de la ley mosaica, se castiga con la muerte de su autor y la destrucción del animal que ha servido a ese fin.

Coito con cadáveres.-También se castiga el coito con cadáveres y se agrava su pena si el autor del delito se adueña del cuerpo de los mismos.

Coito entre mujeres.-Se castiga el coito entre mujeres que ejecutan los actos venéreos de corromperse o, como sucede en muchos casos, servirse de instrumentos materiales que lo facilitan.

Rapto.-Al contarse el rapto entre los delitos merecedores del máximo castigo, la pena de muerte se aplica a sus autores.

Delito de bigamia.-Son punibles el coito del varón que simultáneamente tiene dos o más mujeres y el de la mujer que, al mismo tiempo, tiene dos maridos. Se les aplica respectivamente la pena del estupro y el corte de cabellos, además de declararse la infamia del adúltero.

Ausencia del marido.-Si la mujer cuyo marido se ausentó hace algún tiempo, tiene noticia cierta de su muerte o, según la opinión general, se convence de que ha fallecido y toma otro marido, se la castiga como adúltera y se le absuelve del delito de fornicación.

Uso de la violencia.-Se ha de castigar más gravemente el coito punible que el que ocurre con violencia o empleo de la fuerza.

\section{HURTO}

Concepto del hurto.-Es hurto punible el apoderamiento fraudulento de una cosa ajena, con propósito de lucro relativo a ella o al uso y posesión que de la misma cabe hacer.

Hurto manifiesto.-Hay hurto manifiesto cuando, en el acto de cometerlo, se sorprende al autor que se apodera de la cosa hurtada. También es manifiesto el hurto cuya comisión presencia un tercero que se apresura a denunciarlo.

Autotutela del perjudicado.-El dueño de la cosa hurtada puede entrar, con autorización del juez, en el domicilio ajeno para perseguir el hurto y recobrar aquélla. Aunque algunos sostienen que la autorización debe denegarse, la prudencia aconseja que, para no suscitar escándalo ni alarma, el permiso se otorgue y la pesquisa se confíe a sus propios o más próximos ejecutores. 
Requerimientos e intimaciones.-La publicación de edictos o la emisión de cartas monitorias conminan, bajo pena de excomunión, a indicar dónde se hallan las cosas hurtadas cuyo destino se conozca.

Presunción del hurto.-Aquel en cuyo poder se descubre la cosa hurtada, sólo se presume ladrón si es persona de mala fama, pero no cuando goza de buena fama y condición. No hay indicios bastantes para condenarle, pero sí para someterle a la tortura que puede provocar su confesión.

Gravedad del hurto.-El hurto constituye delito grave si se sustraen objetos muy valiosos o sumas considerables de dinero.

Critica de la pena de muerte.-El Derecho común no castiga el hurto con la pena de muerte, salvo si el valor de la cosa sustraída excede de una determinada cantidad o el delito de hurto concurre con otro merecedor de ese castigo. Se advierte que el hombre, creado a imagen de DIOS, es sacrificado por adueñarse de los bienes ajenos y se predice que quienes así lo deciden arrastrarán una vida infeliz, no gobernarán durante mucho tiempo ni extenderán su imperio más allá de tres generaciones.

Hurtos famosos. - La conclusión no se aplica a los hurtos famosos que cometen los delincuentes habituales o que acarrean la pena de infamia. Se considera ladrón famoso al que, adquirido el hábito de robar, sufre la pena de muerte por la comisión sucesiva de varios delitos de hurto.

Excepción.-Puede imponerse la pena de muerte si, no obstante haberse cometido un solo hurto, es éste de considerable magnitud.

Delito continuado.-La pena máxima se aplica cuando se habla de tres hurtos, sin computarse los cometidos fuera del territorio, mientras que existe un tercer hurto y dicha pena es procedente si los otros dos anteriores ocurrieron dentro del territorio y completan la cifra señalada.

Traslación de la cosa hurtada.-El ladrón que traslada la cosa hurtada a un territorio distinto del suyo, puede ser castigado en el mismo a causa de su apoderamiento.

Adición de la pena.-Ha de ser ahorcado el ladrón que, tras haber consumado dos hurtos y sufrido la pena establecida para cada uno, comete un tercero, pues, amén del castigo de los anteriores, éstos se añaden al perpetrado en último lugar. Otra opinión sostiene que los dos primeros delitos no se computan para imponer la pena máxima y sí para acrecentar la pena correspondiente al tercero.

Ampliación de la regla.-La misma regla se aplica al ladrón que, absuelto de los dos primeros hurtos, comete un tercero que, sumado a los anteriores, se tiene en cuenta para imponerle el máximo castigo.

Individualización de los hurtos.-Cada uno de los hurtos que así se contemplan, consiste en sustraer cosas diferentes de las que el ladrón se apodera en distintos momentos o espacios de tiempo.

Ejecución de la pena de muerte.-La pena de muerte, con que el delito de hurto se castiga, se ha de cumplir por ahorcamiento y no por decapitación. 
Deberes de restituciòn.-El ladrón no está obligado por el fuero de la conciencia a devolver al dueño de la cosa el cuádruplo de su valor y sólo debe restituir la cosa hurtada.

Muerte del ladrón flagrante.-Puede matarse impunemente al ladrón sorprendido en el acto de cometer el delito perpetrado en flagrancia.

Valor y cuantía de las cosas hurtadas.-Si el valor y la cuantía de las cosas hurtadas no constan ni es fácil su demostración, ha de estarse a lo que, bajo juramento, declaren los dueños despojados de tales objetos.

Prueba de la excusa.-El ladrón de la cosa robada se excusa demostrando que la persona a quien se la sustrae era un deudor suyo que había incumplido el deber de restituir mediante el pago de una suma de dinero o satisfacción equivalente.

Excusa del hurto.-El hurto se excusa demostrando que la cosa que se dice sustraída se recibió por decisión de quien entonces era su dueño. Para que haya hurto se precisa que el apoderamiento de la cosa ajena tenga lugar contra la voluntad de aquél. Una cautela razonable consiste en que el propio dueño atestigüe que hizo la entrega voluntariamente. Debe, además de esta protesta, concurrir alguna verosimilitud o conjetura, como el dato de tratarse de parientes consanguíneos o amigos, o el módico valor de la cosa hurtada. La verificación de estos extremos depende del arbitrio judicial.

Hurto doméstico.-Los hurtos domésticos se castigan corporalmente con la pena de muerte y sus autores deben ser ahorcados como ladrones famosos.

Valor módico de la cosa hurtada.-La alegación de que la cosa hurtada es de escaso valor - puesto que no hay que ocuparse de las cuestiones mínimas- resulta inaceptable, ya que la acción de hurto tiende también a recobrar los bienes insignificantes de que se ha visto privado su dueño. El módico valor de la cosa suele tenerse en cuenta para atenuar la pena que el autor del hurto debe soportar.

Estado de necesidad.-Queda excusado el hurto cometido en tiempo y circunstancias de necesidad, pues en semejantes situaciones, es lícito adueñarse de las cosas ajenas.

Mejora de fortuna.-Sostienen algunos que está obligado a devolver la cosa hurtada quien, tras haber cometido un hurto en tiempo y circunstancias de necesidad, mejora posteriormente de fortuna. Prevalece la idea de que, si el Derecho permitió aquel hecho en su momento, no ha de plantearse la cuestión de nuevo ni procederse a la restitución que se debate.

Hurto en naves u hospederías.-Si se comete un hurto en naves o casas de hospedaje, responde el hospedero al que los huéspedes han entregado y consignado su equipaje. Si el equipaje se restituye abierto o estropeado, opinan unos que no merece crédito el huésped que, bajo juramento, afirma que se le han hurtado ciertos objetos que había en la valija, y que el juez debe interrogar a los familiares, sirvientes y otros que se hallen en la casa. De contrario se alega que ha de estarse en un todo a lo que, bajo juramente, ha 
declarado el huésped, pues la experiencia enseña que los hospederos son verdaderos profesionales del hurto y que la aplicación de este criterio ayuda a combatir su falta de honradez.

Restricción del perdón.-Cuando se acciona criminalmente, no rige el principio de que, si varios siervos han cometido un delito de hurto, el perdón otorgado por el dueño a uno de ellos libera a todos los demás.

\section{CRIMEN DE HEREJÍA}

Concepto del crimen de herejía.-Se incurre en herejía cuando los artículos de fe se sienten y entienden de distinto modo a cómo los siente y entiende la Iglesia romana. También es hereje el que disiente de los sacramentos de la Iglesia, defiende una doctrina perversa, difunde nuevas opiniones o secunda las antiguas que la Iglesia condena. Así se manifiestan quienes aseguran que el perjurio y la fornicación no son pecado.

Condiciones del crimen de herejía.-Para ser declarado hereje hace falta estar bautizado, de suerte que los judíos, los paganos y los mahometanos no incurren nunca en crimen de herejía. Se requiere, además, errar conscientemente sobre materias de la fe católica, acatando lo falso en lugar de lo verdadero, lo incierto en lugar de lo cierto y viceversa. No se considera hereje a quien sólo es inicialmente pertinaz en esas opiniones, ni al poseedor de una fe implícita, que cree en todo lo que acepta y enseña la Santa Madre Iglesia, aunque, a impulsos de la razón natural, opina falsamente sin llegar a difundir sus errores. Se incurre en herejía desde el momento en que la duda se consolida, gana en firmeza de ánimo y adquiere la consistencia con que se transforma en error.

Negación de palabra.-Quien, por miedo al tormento, la muerte u otra causa, niegue a CRISTO de palabra, pero siga creyendo en ËL de corazón, comete un gravísimo pecado mortal, pero no se le tiene por hereje, pudiendo obtener del Obispo la absolución y la conciliación que le devuelven al seno de la Iglesia.

Carácter del crimen de herejía.-El crimen de herejía es delito eclesiástico y sólo los jueces eclesiásticos pueden conocer del mismo. Incumbe a los jueces seculares ejecutar la pena que, por la comisión del delito, se haya impuesto al hereje.

Variantes de auxilio judicial.-El juez secular, al que el juez eclesiástico hace entrega de un reo de herejía, puede conocer de ciertos particulares de la causa sin alterar la pena recaída. El juez laico puede hacer detener al sospechoso de herejía para ponerle, sin demora, a disposición del juez competente.

Jurisdicción ordinaria y jurisdicción delegada.-Los jueces ordinarios, los Obispos, que entienden de las causas abiertas contra los herejes, los jueces delegados y los inquisidores investigan el delito en cuestión. Unos y otros pueden actuar simultánea o divisiblemente, si bien la condena del reo requie- 
re la intervención de todos ellos. Pueden, en cambio, absolver por separado del crimen de herejía.

Competencias declarativas y ejecutivas.-El juez eclesiástico, que entiende del delito, sólo puede declarar la incursión del reo en crimen de herejía y condenarle a morir en la hoguera, entregándole luego al juez secular para la ejecución del máximo castigo.

Ejecución y conmutación de la pena de hoguera.-La pena de muerte en la hoguera se aplica al hereje que rehúsa retornar al seno de la Iglesia. Si hace penitencia y está dispuesto a abjurar de su herejía, elude las penas establecidas para los herejes, pero no la condena a cárcel de por vida. Los superiores y los inquisidores pueden conmutar esta pena por otra más leve, entendiendo por superiores a los jueces eclesiásticos, pues los jueces civiles no son competentes al respecto. Los herejes reincidentes han de sufrir la pena de hoguera, aunque se ofrezcan a hacer penitencia y regresar a la fe de la Iglesia. Si el hereje no reincidente hace penitencia y se dispone a abjurar de su error antes de que se dicte la sentencia, no sólo sortea la pena de muerte, sino también la de confiscación de sus bienes que produce efectos de pleno Derecho desde la comisión del delito.

Momento idóneo para la penitencia.-Según unos, la penitencia sólo es eficaz cuando, inmediatamente después de advertirse el error, los herejes vuelven voluntariamente a la verdad y la unidad de la Iglesia. Defienden otros que el arrepentimiento es admisible hasta que se dicte sentencia. La opinión más extendida entiende que la retractación y el arrepentimiento surten efectos incluso después de la condena del hereje.

Equivocidad de la actitud herética.-Cuando el imputado convicto de herejía manifieste el propósito de abjurar y de reconocer su error, aunque luego rehúse confesar que dijo tal y asegure que estuvo siempre dispuesto a creer en lo que la Iglesia manda y cree, su abjuración carece de valor y, a causa de su negativa, debe ser quemado por impenitente, salvo que pruebe haberlo dicho porque estaba convencido de ello. Esta doctrina es harto severa y criticable, pues mal puede considerarse hereje a quien no persevera tenazmente en el error que se le atribuye.

Cumplimiento de la penitencia pública.-Si el hereje no quiere hacer la penitencia pública que se le ha impuesto para constancia de su error, debe ser quemado en la hoguera. Un criterio de benignidad aconseja que se le destierre durante seis meses de la ciudad donde reside, salvo si concurren circunstancias indicativas de que no comparte el sentir y la fe de la Iglesia. Debe entonces ser arrojado a las llamas como reincidente.

Condición del hereje impenitente.-Los herejes impenitentes no han entregarse de inmediato a los jueces seculares, como si se tratase de herejes reincidentes, sino que deben ser avisados y exhortados para que retornen a la fe. Pueden beneficiarse de la reconciliación allí donde, por fin, cumplan la penitencia pública. 
Pena de confiscación por herejía.-El Derecho común manda confiscar todos los bienes de los convictos de herejía. Además de la confiscación producida de pleno Derecho, el reo pierde la administración de esos bienes desde la comisión del delito. Los bienes de los clérigos herejes, titulares de un beneficio eclesiástico, pasan a la Iglesia de que son beneficiados, y, si no tienen beneficio, al fisco de la Iglesia catedral. Los bienes de los laicos herejes se destinan al fisco secular. En España, los bienes muebles de los herejes, incluso los de los clérigos beneficiados o no, se destinan al fisco secular. No faltan otras soluciones afines y ocasionalmente extravagantes sobre el particular.

Extensión subjetiva de la confiscación.-Los bienes de los declarados herejes se confiscan, aunque uno o varios de sus hijos sean católicos o cristianos ortodoxos.

Separación matrimonial por causa de herejía.-La incursión en crimen de herejía da lugar a la separación del matrimonio. La esposa que rechaza al varón reincidente en herejía, con o sin sentencia, está obligada a volver a su lado si el marido retorna al seno de la Iglesia, salvo que, si la sentencia lo autoriza, prefiera entrar en Religión.

Condición del clérigo hereje.-El clérigo hereje queda privado de los oficios y beneficios eclesiásticos de que está en posesión. También los hijos de los clérigos herejes y sus encubridores pierden los beneficios que ostentaban cuando se cometió el delito. Un criterio de benignidad aconseja que esta última privación se produzca merced a una sentencia.

Retroactividad de las penas.-Las penas decretadas contra los hijos de los declarados herejes afectan indistintamente a los nacidos antes de que sus padres delinquieran o después de cometido el crimen, si bien la opinión más benigna desaconseja la aplicación del castigo a los primeros.

Relaciones con el condenado.-Los particulares que tienen relación o trato con los condenados por crimen de herejía, no deben presumir la buena fe de estos convictos.

Asistencia y representación de los herejes.-Los herejes no pueden ser asistidos por los abogados y procuradores cuando su condición de tales sea evidente, salvo si el abogado pretende probar en el juicio que su patrocinado no es hereje y desea volver a la fe católica. En las causas contra los herejes, los Obispos y los inquisidores suelen autorizar a los abogados para que intercedan, aunque no se haga uso frecuente de la venia otorgada.

Prueba del crimen de herejía.-Para demostrar la incursión en crimen de herejía, bastan elementos menos consistentes que en la generalidad de los procesos, no sólo durante la averiguación o inquisición del delito, sino también para concluir que hay prueba plena de haberse cometido. No es aceptable la opinión de que, para declarar convicto de herejía, se exige la declaración de tres testigos, en vez de los dos que habitualmente se requieren.

Persecución postmortuoria del crimen de herejía.-El crimen de herejía puede perseguirse después de la muerte del hereje, al que se impone tar- 
díamente la pena de condena o proscripción de su memoria. El cuerpo de los herejes así condenados se entrega al brazo secular que decreta su quema en la hoguera. La condena de la memoria no sólo se aplica a los verdaderos herejes, declarados tales en virtud de pruebas convincentes, sino también a los herejes presuntos que, llamados a la causa y no comparecidos, mueren cuando transcurre más de un año sin haber depuesto su actitud contumaz.

Excepción respecto al Papa.-Aunque el Papa no puede ser acusado ni perseguido por delito alguno, sí que cabe declararle hereje y condenarle por la comisión de ese crimen.

Condición del hereje oculto.-Los herejes ocultos, que sólo en su interior se apartan de la fe católica y no muestran, de palabra o por escrito, señal alguna de herejía, no incurren en la pena de excomunión ni en el resto de las fijadas para los herejes. La Iglesia no juzga ni resuelve sobre las realidades ocultas o de objetivación imposible.

Hechos constitutivos de herejía.-Son hechos que, a juicio de los especialistas, constituyen crimen de herejía, los que dan a entender algo manifiesta e inequívocamente herético, como bautizar las imágenes, bautizar nuevamente a los niños y otros semejantes.

Invocación del demonio.-La invocación del demonio denota la incursión en herejía manifiesta, pues atribuye al diablo la predicción y el conocimiento del futuro que es obra de DIOS. Si la invocación se hace para poner a prueba la virtud y el pudor de la mujer, no hay crimen de herejía, porque se invita al demonio a realizar lo que más le satisface, como es la tentación del un alma para adueñarse de ella. Crímenes como el de sortilegio son de fuero común y de ellos pueden conocer los jueces eclesiásticos y los jueces seculares. El Derecho común castiga los sortilegios y las adivinaciones con la pena de muerte y la confiscación de bienes, aunque la práctica consuetudinaria suele sustituirlas por las penas de azotes y expulsión de la comunidad.

\section{HOMICIDIO}

Modalidades del homicidio.-A diferencia de los animales, los hombres recelan unos de otros y se arrebatan la vida con crueldad. Las modalidades del homicidio son el homicidio simple y el homicidio deliberado. El homicidio simple se comete sin intención o ánimo específico de matar. El homicidio deliberado se comete de propósito y con ese carácter, El homicidio simple puede obedecer a necesidad, casualidad, culpa o dolo.

Homicidio casual.-El homicidio es casual si, al intentar hacer algo que le está permitido y sin culpa alguna de su parte, una persona causa la muerte de otra.

Homicidio culposo y pena que le corresponde.-El homicidio se comete con culpa cuando, inadvertidamente y sin ánimo de matar, una persona causa la muerte de otra. Aunque este homicidio se realice sin dolo, debe castigarse 
con pena pecuniaria o con destierro y no con la pena ordinaria de muerte. Siempre ha de reprimirse con más benevolencia el homicidio cometido sin propósito de matar, que el que tiene lugar dolosamente. El homicidio culposo se castiga penalmente cuando el autor obró con culpa lata, cercana y semejante al dolo, pero no si la culpa es levísima o leve. Esta última se equipara al caso y el homicidio que se sigue de ella lleva el nombre de homicidio casual.

Agresión producida sin ánimo de matar.-También hay homicidio culposo si, sin intención de matar, alguien golpea a otra persona que muere a consecuencia de esta percusión. Se cita el ejemplo de la mujer que, golpeándola en la cabeza con un bastón, ocasiona la muerte de la sierva que consideraba encinta de su marido. No hay ánimo de matar si, sin propósito de golpear a otro, se le acomete por error y de ello se sigue la muerte, o si, para defenderse del ataque de un animal, se lanza contra él un objeto que alcanza a un transeúnte que fallece a consecuencia del impacto.

Homicidio de persona distinta de la que se propone matar el autor.Si alguien quiere matar a un persona $y$, sin lograrlo, da muerte a otra distinta, no se le ha de imponer la pena extraordinaria propia del homicidio, pues no ha intervenido la voluntad de eliminar a quien así queda privado de la vida. Se trata de un homicidio cometido por culpa y no por dolo. Si alguien se incorpora a una riña desencadenada con ánimo de matar y muere a consecuencia de esta participación, se le declara muerto en riña y no de propósito o en virtud de un ánimo deliberado.

Homicidio doloso.-Existe homicidio doloso cuando, con ánimo deliberado, un hombre causa la muerte a otro. Se denomina homicidio simple, porque el propósito de matar no va precedido de un intervalo o tiempo de reflexión y sobreviene repentinamente al calor de la ira o en el transcurso de una riña.

Modos de comisión del homicidio deliberado.-El homicidio deliberado puede cometerse de propósito, por insidia, a traición o por asesinato.

Homicidio cometido de propósito.-El homicidio se comete de propósito cuando una persona da muerte a otra con ánimo deliberado y sostenido durante un intervalo de tiempo anterior a la agresión. Esta pausa es precisa, porque, si alguien tropieza con un enemigo y, acalorado por la ira, le da muerte, el ánimo deliberado no existe, salvo si se acredita que la agresión tuvo lugar preparando las armas con el fin de matar al adversario tan pronto como con él se diese. La zona del cuerpo en que se produjeron las lesiones, la clase de armas y las heridas de los contendientes permiten presumir la intención de matar, pero no el ánimo deliberado anterior a la agresión. Cuando, inmediatamente después de haber sido injuriado, el ofendido mata al ofensor, se conjetura verosímilmente que, aun sin intervalo previo a la toma de la decisión, ya el primero había resuelto cometer el homicidio.

Homicidio cometido por insidia.-El homicidio se comete por insidia cuando una persona espera a otra en un lugar donde ésta no puede prever la 
presencia de aquélla y, viéndola venir, arremete contra ella, con ánimo de matarla, y le quita la vida. Los autores de estos homicidios no gozan de la inmunidad que procura el asilo eclesiástico.

Homicidio proditorio.-El homicidio se denomina proditorio cuando una persona da muerte a otra sin estar previamente enemistadas. Es el caso de que un compañero de viaje mate a otro o de que, sin que preceda riña, dos socios se hallan sentados a la mesa o una persona finge ser amiga de otra. Tampoco goza de inmunidad al autor del homicidio proditorio o cometido a traición que postula el asilo eclesiástico.

Homicidio por asesinato.-El homicidio constituye asesinato si se comete a cambio del pago de una suma de dinero.

Modos de comisión del homicidio.-El homicidio se puede cometer de varios modos. Unas veces, el autor lo ejecuta con sus propias manos. Otras, encarga su comisión a otro, entendiéndose que este mandato de homicidio equivale a su ejecución por el que le ordena. Otras, auxilia a un tercero o le aconseja la comisión de un homicidio. Se considera también homicida a quien intenta darse muerte o se quita la propia vida. Es homicida el que añade a la comida o la bebida algo mortífero, cuya ingestión, como es el caso de los vasos amatorios y los vasos de aborto, causa la muerte del consumidor. Es homicida quien indica a otro que siga una ruta donde sabe que sus enemigos están apostados para darle muerte.

Homicidio por envenenamiento.-Se castiga también como homicida a quien fabrica venenos mortíferos o se los facilita a otro para que mate usando de ellos. Cuando la muerte es consecuencia del envenenamiento, se ha de imponer la pena capital a quien ha facilitado el veneno.

Envenenamiento sin resultado de muerte--Aunque el envenenamiento no produzca la muerte, debe aplicarse la pena ordinaria, pues este crimen se considera de máxima gravedad o muy atroz. Ello no obstante, la opinión general entiende que ha de castigarse con penas menos graves.

Homicidio por condena injusta.-Al juez que, corrompido por el dinero o a impulsos de la ira, condena a muerte a un inocente, se le aplica la pena de decapitación por homicidio. Pena que procede imponer si ha dado crédito a una acusación falsa o a una pesquisa que han motivado la condena de un inocente a pena capital.

Homicidio causado por torturas.-Debe ser condenado a pena capital, como homicida, el juez que somete al reo a una tortura desmedida o se excede en las investigaciones que originan la muerte de aquél.

Homicidio causado por la administración de un mal medicamento.Comete homicidio el médico que, a sabiendas, administra un mal medicamento que produce la muerte del enfermo. Si no consta ni se acredita que conocía esa maldad, se le impone una pena de gravedad menor. Si el enfermo fallece a consecuencia de la culpa o la impericia del médico, éste ha de resarcir los daños causados por su intervención. 
Pena del homicidio.-El homicidio se castigaba con la pena de deportación y confiscación de todos los bienes del reo que fuese de noble condición. Se ha sostenido luego que tanto los homicidas plebeyos como los de noble condición deben ser condenados a muerte.

Imposición exclusiva de pena pecuniaria.-Carecen de valor las disposiciones que limitan el castigo del homicidio a la imposición de una pena pecuniaria.

Sanciones del Derecho Canónico.-El Derecho Canónico castiga con la pena de excomunión el homicidio cometido por laicos, y con la deposición de su cargo y la pérdida de beneficios el que los clérigos pueden cometer.

Condición del clérigo homicida.-El clérigo homicida pierde sus beneficios por el mero hecho de haber dado muerte a una persona, sin requerirse una sentencia que acuerde dicha privación. La sentencia se exige en el caso del homicidio simple, pero no, si el homicidio es deliberado o cualificado por alguna circunstancia de agravación.

Desheredación del homicida.-El homicida pierde su derecho a heredar, por testamento o abintestato, a la persona a la que dado muerte. La exclusión no tiene lugar como incapaz, sino después de que, habiendo sido llamado a suceder, el fisco se adjudique la herencia. El hijo, que ha dado muerte al padre, le sucede y el fisco se adueña de la sucesión a causa de la indignidad del heredero.

Sufragio del alma.-En sufragio del alma del muerto, el homicida viene obligado a dar limosna para que se recen plegarias, a ayunar y, en la medida de sus recursos económicos, a sufragar los gastos médicos de curación, teniendo en cuenta los hábitos del enfermo y el tiempo que aquélla hubiese requerido en el caso de sobrevivir. El fisco no acostumbra a valorar previamente los bienes del homicida, para indemnizar a los hijos del fallecido, y se los apropia sin fijar antes el importe del resarcimiento.

Excusas del homicidio.-Entre las causas que excusan el delito de homicidio, está la prueba de que se cometió para la defensa necesaria del autor de la muerte. Tampoco es punible el homicidio cometido en defensa propia, pues cada uno puede rechazar lícitamente, con la fuerza, la violencia ejercida contra su persona. Criterio al que los teólogos no oponen objeción alguna.

Homicidio excusado por la defensa de los bienes.-La licitud de dar muerte a otra persona en circunstancias de defensa propia, no sólo se refiere a la protección del cuerpo y de la vida, sino también a la de los bienes pertenecientes a quienes reaccionan así. El Derecho Canónico no excusa el homicidio del ladrón por el poseedor o el propietario de las cosas que aquél ha sustraído.

Homicidio excusado por la defensa del honor.-Con mayor razón, es lícito dar muerte a otra persona para defender el honor propio, pues el peligro de la fama o estimación personal se asimila al peligro de la vida. Quien sufre riesgo inminente de injuria o daño personal puede matar impunemente al agresor. 
Homicidio excusado por la defensa de los allegados.-La excusa no sólo alcanza a la defensa de los que protegen la integridad personal, sino también a la de quienes mantienen con ellos vínculos de sangre.

Homicidio excusado por la defensa de extraños.-La excusa se amplía a la defensa ejercida por algunos extraños, como los que forman parte de la familia del agresor o están a su servicio.

Homicidio del clérigo ofensor.-La excusa del homicidio prevalece cuando, partiendo la agresión de un clérigo, se le da muerte en defensa de la persona, de sus parientes y de algún extraño.

Homicidio del Papa o el Emperador.-Se excusa incluso el homicidio del Papa y/o el Emperador, si uno u otro intenta, contra todo Derecho, agredir a una persona que, ni siquiera acudiendo a la fuga, puede salvarse de la muerte inminente a que le expone dicho ataque. Quien, en defensa propia, agrede a un clérigo, no incurre en la pena de excomunión, aunque, sin excederse de propósito, se haya extralimitado en su respuesta.

Homicidio del insultante.-No se permite que el insultado dé muerte al insultante, sino también a quien, no siendo el ofensor, es imprescindible matar para evitar la intervención del agresor.

Recurso a la fuga.-Aunque el insultado puede salvarse huyendo, no tiene obligación de hacerlo y puede matar impunemente al insultante, si bien ello depende de que la fuga se produzca honorable o deshonrosamente.

Prueba de la necesidad de defenderse.-No es preciso que el agresor demuestre la concreta necesidad de su defensa, pues le basta acreditar que obró movido por la intención de defenderse. Tampoco hay que aguardar a que el agresor ofenda o acometa, pues el sentirse amenazado de muerte ya excusa el homicidio de la persona de quien se teme un inminente ataque.

Exceso en la defensa.-La defensa invocada para excusar el homicidio debe ejercitarse con la moderación propia de la tutela pretendida, conforme al modo, el tiempo y la causa que concurren en ella. Al agredido que dolosa o culposamente se excede en el modo de defenderse, no se le impone la pena ordinaria del homicidio y sí otra más tenue que el juez determina. La excusa no interviene cuando, acabado el enfrentamiento o la pelea, el herido insulta al que causa la lesión, pues entonces no median motivos de defensa y sí razones de venganza. El que mata al agresor para defenderse sufre una pena más leve que la pena capital.

Prueba sobrevenida.-Se admite la prueba tardía de quien, habiendo negado en el proceso que diera muerte a otro y alegado que, a causa de la tramitación, se le considera reo de homicidio, trate de acreditar que obró en defensa propia. El reo no puede oponer diversas y sucesivas excepciones que se contradigan.

Homicidio del sujeto insidioso.-El homicida se excusa demostrando que aquel a quien dio muerte se disponía a tenderle una emboscada y acecharle para privarle de la vida, pues es lícito adelantarse y matar a esos traidores. 
Ello también ocurre cuando la inminencia y el advenimiento del acecho sólo se evitan dando muerte al traidor. Aunque el homicida hubiese podido detenerse o suspender su iniciativa, no se libraría de la imposición de una pena extraordinaria.

Intervención de varias personas en el homicidio.-Cuando es imposible identificar al autor del homicidio entre quienes en él participaron, se cuestiona si, ante esa incertidumbre, todos deben ser condenados o absueltos. Si solo hay una herida letal y se ignora quien sea su causante, no ha de imponerse la pena ordinaria y sí castigarse a todos con una pena pecuniaria. Si hay varias heridas letales y se ignora cual de ellas originó la muerte, procede absolver a todos de la máxima pena e imponerles una pena al arbitrio del juez. Se contemplan, además, tres supuestos. En el primero, si el homicidio es deliberado y cometido de propósito, procede imponer a cuantos intervienen en él la pena ordinaria del homicidio, tanto si el difunto fallece a causa de una sola herida como de varias, aunque sólo sea letal una de ellas y las restantes no, y aunque conste que todos hirieron o no hirieron o surjan dudas al respecto. En el segundo caso, si no consta que el homicidio se cometió deliberadamente y hay incertidumbre sobre el particular, todos los intervinientes deben ser condenados a la pena extraordinaria propia del homicidio simple. El tercer caso surge cuando, fuera de toda duda, el homicidio se comete de improviso en el curso de una discusión.

Homicidio cometido en riña.-Cuando, en una riña, sólo existe una herida que causa la muerte de la persona lesionada, pero se desconoce quién de los participantes haya sido su autor, ha de imponerse a todos la pena extraordinaria que fija el arbitrio del juez y no la pena ordinaria que corresponde al homicidio. Si una persona es golpeada por varias y se desconoce a consecuencia de qué ha fallecido, no se impone la pena de muerte a ninguno de los agresores.

Presunción de autoría.-La aparición del autor principal o del iniciador de la riña genera una válida presunción de Derecho, por la que sólo a él se le considera homicida y puede ser decapitado. Este criterio no se observa y pocas veces se castiga con la pena de muerte el homicidio cometido durante una pendencia.

Desconocimiento de la identidad del homicida.-Cuando, ignorándose quién ha causado la lesión, es imposible identificar al homicida, se sostiene que, si la pena del homicidio se equipara a la de auxilio al mismo, el juez puede acusar a uno de homicidio y a los demás de auxilio. Algunos acusan de homicidio, describiendo el hecho y declarando que uno hirió y los demás le auxiliaron, sin designar nominativamente al homicida. Si son contumaces, se les condena en rebeldía a la pena del homicidio. Si comparecen, se les aplica la tortura o se les impone una pena pecuniaria.

Desconocimiento de la herida letal.-Aun constando la producción de varias lesiones, la identidad de los autores respectivos e incluso de las que ha 
causado cada uno, puede ignorarse la que originó la muerte. Si todas ellas son letales, los componentes del grupo agresor son acusados de homicidio. Si unas resultan letales y otras no, los autores de las primeras son declarados reos de homicidio y los restantes de lesiones.

Alegación de una causa diferente.-Los acusados de homicidio suelen defenderse alegando que la muerte del herido se debió a una causa diferente y extraña a las lesiones que se le infligieron. Si hay certeza de que la herida es letal, su autor es castigado con la pena extraordinaria correspondiente al homicidio. No sirve invocar la impericia de los médicos ni la culpa del herido o enfermo que, pudiendo acelerar su muerte, no excluyen la acusación por homicidio. Si se prueba que la herida no es letal y que la muerte proviene de otra causa, no cabe acusar por homicidio. Si, dudándose de la letalidad o no letalidad de la herida, tampoco consta negligencia o culpa del fallecido, se presume que éste ha muerto a causa de dicha lesión y se entiende que el homicidio existe. Si consta la negligencia o culpa del herido, se impone al causante una pena extraordinaria, en vez de la pena ordinaria del homicidio.

Criterio de los médicos.-Hay que estar al criterio de los médicos y peritos que dictaminan si la muerte provino de la letalidad de la herida o de un desacertado tratamiento. Basta el parecer de uno solo, si no hubiese más en el lugar. Los peritos no han de ser doctores, porque estas curaciones también se encomiendan a los cirujanos y barberos que, como los médicos, deben prestar el juramento que no asegura la veracidad de su juicio, sino sólo su credibilidad y prestigio. Cuando los médicos se dedican especialmente a visitar, sólo han de prestar juramento al comenzar esas visitas y no en el curso de cada una de ellas. Frecuentemente aseveran los peritos que la muerte ha sido consecuencia de un mal tratamiento. Poco crédito merecen los peritos que, para favorecer indulgentemente a los acusados, dictaminan en juicio que la herida no era letal o que el fallecimiento se debió a mala práctica, pues los casos de corrupción son abundantes. La opinión más sensata manda estar al arbitrio judicial, que pondera la cualidad, el lugar de la herida y el parecer de los facultativos que declaran si la herida ha producido efectos a causa de su intervención o del tiempo transcurrido entre la producción de la lesión y el fallecimiento.

Muerte del herido en un corto espacio de tiempo.-Si, después de haber sido lesionado, el herido empeora y fallece al cabo de un breve espacio de tiempo, se presume que ha muerto a consecuencia de dicha agresión y se considera homicida a su autor. Los médicos afirman que quien soporta una herida letal no sobrevive más de cuarenta días. No se presume que la muerte sea consecuencia del ataque sufrido, si el herido deambula durante más de tres días después de la agresión.

Corrección del error de los médicos.-Si, en virtud del dictamen de los médicos, alguien es declarado homicida y se demuestra luego que la imputación no procedía, cabe que aquéllos se retracten y que se dé por 
bueno el parecer de otros expertos, pues la sentencia no produce efectos de cosa juzgada. Se discute si la solución es admisible cuando no caben remedio ni recurso contra la resolución recaída. A petición del imputado, el juez puede designar peritos que, exentos de toda sospecha, revisen el parecer anticipado por los médicos e informen de la letalidad de las heridas causadas.

Prueba de otra causa del homicidio.-Puede demostrarse que el herido no ha muerto a consecuencia de la lesión causada por el reo, si se prueba que sobrevino otra agresión que le privó de la vida. Ha de absolverse entonces a quien, a juzgar por lo ocurrido, no es un verdadero homicida. Es desafortunado aconsejar que quien ha herido mortalmente a otro encomiende de inmediato a un tercero que le dé muerte, para que el uno sea sólo acusado de lesiones y el otro de homicidio. Si éste interviene por mandato o voluntad del primero, ambos incurren en pena de homicidio. Si esa voluntad falta, el primero es acusado de lesiones y el segundo de homicidio.

Licitud de la muerte de un ladrón.-El reo puede alegar, como excusa, la impunidad de haber dado muerte a un ladrón, a un bandido o a un adúltero. Para excusar la muerte del ladrón nocturno, hace falta que se defienda la propia persona o la toma de las cosas de su propiedad, pues no hay excusa cuando el ladrón desiste de apoderarse de ellas. Hay que pedir auxilio antes de dar muerte al ladrón nocturno. Es preciso disponer de testigos que demuestren el propósito de hurtar. Es, en fin, necesario que haya sido imposible capturar al ladrón. Se puede matar al ladrón diurno que se defiende con la espada o al que, dudándose de si tiene propósito de matar o de hurtar, no se puede hacer frente sin riesgo de la vida. La impunidad del homicidio se da cuando el ladrón se apodera de las cosas de su dueño y, huyendo con ellas, se resiste violentamente a devolverlas.

Excusa favorable al padre.-El padre puede matar impunemente al varón que comete adulterio con su hija, siempre que medien estas condiciones. La hija ha de estar casada y sometida a la patria potestad. El episodio ha de tener lugar en el domicilio del padre o de su yerno. Los adúlteros han de ser sorprendidos en el acto de la comisión del adulterio. Los clérigos y los magistrados adúlteros no se eximen de esa circunstancia.

Excusa favorable al marido.-El marido que, sin haber consentido el adulterio, sorprende a su esposa cohabitando con un varón de condición vil, sólo puede matarle impunemente si el adulterio se comete en su propia casa, pero no si se produce fuera de ella. Si el adúltero no es persona vil, el marido no puede matarle impunemente, aunque, a causa de su justificado dolor y humillación, se le imponga una pena más tenue que la del último suplicio. También se mitiga la pena del marido que golpea al clérigo sorprendido en flagrante adulterio con su esposa. La atenuación beneficia al prometido con esponsales por palabras de futuro y no exige la absolución del Sumo Pontífice, porque la del Obispo es bastante. 
Excusa en el fuero de la conciencia.-A diferencia del fuero contencioso externo, el fuero de la conciencia prohíbe que el padre o el marido dé muerte a la esposa, la hija o el tercero sorprendidos en flagrante adulterio. Parece poco edificante la solución permisiva de que una ley vigente autorice a cometer un pecado mortal.

Excusa de un tercero.-Se duda de si el padre o el marido pueden ordenar a un tercero que dé muerte al adúltero sorprendido en su domicilio. El caso desborda lo habitual, pues implica la posibilidad de tomarse la justicia por su mano, aunque se considera equitativo confiar esta acción a un hijo del padre o del marido.

Muerte del desterrado.-Los homicidas suelen defenderse alegando que el ofendido es un desterrado al que se puede matar impunemente. Lo cual no es así, pues está prohibido dar muerte al enemigo, salvo si el que se ha pasado a sus filas conoce y puede revelar secretos justificantes de tal impunidad.

Validez de la norma que lo autoriza.-La ley no sólo rige cuando dispone que el desterrado puede ser impunemente muerto u ofendido, sino también cuando recompensa estas acciones. Es indispensable que el destierro sancione la comisión de un delito grave, pues carece de valor la disposición que autoriza a ofender o matar por el impago de una deuda pecuniaria.

Fuero de la conciencia.-Se discute si en el fuero de la conciencia es censurable ofender y dar muerte al desterrado. Se alega que quien así procede se excusa en conciencia, porque elimina a un enemigo de la república. Si lo hace con el fin de derramar su sangre, no queda excusado y peca mortalmente, salvo si es claro su designio ajeno a la venganza. En el fuero contencioso, siempre se excusa a quien da muerte al desterrado, aunque lo haga con el propósito de vengarse.

Extensión de la excusa.-Las normas estatutarias disponen que, si el desterrado puede ser muerto impunemente, el agresor se exime de la pena asignada al homicidio. Se pregunta si, cuando sólo se declara que puede ser ofendido impunemente, cabe entender que también impunemente se le puede dar muerte. La opinión general resuelve afirmativamente esta duda.

Impunidad del adulterio con mujer desterrada.-Se cuestiona si cualquiera puede cometer adulterio impunemente con una mujer desterrada. La respuesta es afirmativa, ya que, si el estatuto se dicta para preservar la paz y el orden público, el adulterio cometido con mujer desterrada no altera esa tranquilidad. Tal adulterio se considera impune, por quedar al margen de los objetivos que protegen las normas estatutarias.

Equiparación del deportado.-A estos efectos y según la opinión general, el deportado se asimila al desterrado.

Muerte del padre desterrado a manos de su hijo.-El hijo puede matar impunemente al padre desterrado, que se ha convertido en un enemigo de la patria. La solución rebosa impiedad y crueldad, al introducir una ficción que, en situación tan desproporcionada, no puede desnaturalizar la esencia y los 
efectos de la patria potestad, salvo que, de verdad y no simuladamente, el padre haya sido enemigo de la patria y tomado las armas contra ella, en cuyo caso el hijo se aprovecha de la excusa otorgada. Si el vasallo no puede ofender impunemente a su señor, mayores son la reverencia y el respeto que, en circunstancias semejantes, debe el hijo al padre cuya muerte no ha de quedar impune.

Muerte de quien ha prometido no ofender.-Si alguien concluye la paz con su enemigo y, bajo pena, promete que no ha de ofenderle, surge la duda de, si, al convertirse ese enemigo en desterrado después de hecha la paz, quien la pactó con él puede ofenderle impunemente. La respuesta afirmativa se funda en que la cualidad de desterrado se ostenta y tiene en cuenta tanto al tiempo de concertarse la paz como después de haberla convenido, de donde se sigue la impunidad del ofensor. La impunidad también existe cuando, no siendo un desterrado el ofendido, tal condición se adquiere en virtud de una causa sobrevenida y distinta de la que motivó el acuerdo de paz con su ofensor. No se da impunidad cuando la condición de desterrado se adquiere apenas iniciada la paz o el destierro, o deriva de la misma causa por la que la paz se había estipulado.

Muerte a traición del desterrado.-Parte de la opinión juzga admisible matar a traición al desterrado, privado de la oportunidad de defenderse, mediante el pago de una suma de dinero o encomendando la tarea a un súbdito de quien ordena su eliminación. La opinión minoritaria invoca el ejemplo, que provocó una enconada disputa, de haberse concertado la paz con un enemigo a quien después dio muerte el ofensor, no obstante el acuerdo ultimado y la cautela satisfecha para asegurar su cumplimiento. Es pacífico entonces que el ofensor sufra la pena capital.

Muerte del desterrado aun no publicada.-El desterrado que ha dejado de serlo por la gracia del Príncipe pendiente de publicar o difundir, puede ser muerto impunemente y no cabe atribuir al ofensor culpa alguna por no estar al tanto de esa circunstancia. Lo equitativo es averiguar cuidadosamente si se ha cancelado aquel antecedente y no precipitarse a cometer un homicidio que -doloso por naturaleza- provoca la general reprobación. Si, cuando se halla a punto de ser muerto, el desterrado sólo hace valer que ha obtenido la gracia del Príncipe, el homicidio sigue siendo impune, salvo si, al formular ese alegato, se demuestra fidedignamente que ya se le había perdonado.

Muerte del desterrado por una decisión anulada.-La duda se acrecienta cuando, habiéndose anulado el destierro, se pregunta si hay excusa para el que mata al desterrado cuya condición de tal se ha declarado sin efecto. Sostienen algunos que no cabe la impunidad, aunque el ofensor ha de ser castigado con pena ordinaria si, al tiempo de causar la muerte, ya conocía la declaración de nulidad. Si la ignoraba, debe ser castigado con pena extraordinaria al arbitrio del juez. Esta última solución no convence, pues quien mata al desterrado condenado y luego puesto en blanco, probablemente ignora la nulidad de la condena al destierro y debe beneficiarse de la excusa. 
Impunidad de la muerte del desterrado cuya condena no es firme.¿Puede ofenderse impunemente al desterrado mientras está pendiente la apelación contra la sentencia? La opinión común se inclina por una respuesta negativa, cuando, en las causas criminales, el recurso de apelación se interpone automáticamente contra la condena.

Muerte del desterrado ya aprehendido.-Tampoco puede ser ofendido impunemente el desterrado que ha sido capturado por los servidores oficiales.

Muerte del desterrado fuera del lugar en que se le condena.-Es común la opinión de que no ha de aplicarse la pena capital a quien da muerte al desterrado fuera del territorio de que se le ha expulsado. Las opiniones se dividen cuando quien mata u ofende al desterrado fuera de su lugar de origen, es capturado en un territorio donde cabe matarle impunemente.

Situación del que mata a quien ignoraba que fuese desterrado.-Quien ofende o mata a un desterrado cuya condición de tal ignora, goza del beneficio estatutario de la impunidad. Si bien elude la pena capital asignada al homicidio, el ofensor no tiene derecho a percibir el premio o recompensa ofrecidos al causante de esa muerte $u$ ofensa.

Limitación de orden económico.-Quien es declarado desterrado en sendas causas por importes respectivos de 50 , no ha sido condenado por la totalidad de 100 que permite matar u ofender impunemente. Si el juez condena, por muchos delitos separados, a un total comprensivo de las sumas de cada uno de ellos e inferior a 100, el ofensor o el homicida está excusado.

Carácter de la excepción estatutaria.-La defensa o excepción favorable al acusado es perentoria y no da lugar a la litis contestatio.

Oposición por medio de Procurador.-Si oficialmente se procede contra el que ha dado muerte al desterrado de este modo, puede oponerse una excepción por medio de Procurador o cualquier componente del pueblo que comparezca en el proceso para solicitar que, no obstante la ofensa inferida al desterrado, la causa se paralice y el ofensor resulte absuelto. Es preciso que el destierro sea notorio y que, como prueba del mismo, sólo se admita la aportación de la sentencia de condena.

Derecho del desterrado a defenderse del ataque.-Sobre si el desterrado puede defenderse contra el ataque de quien intenta darle muerte, hay opiniones cuya diversidad no permite concluir la absoluta veracidad de una de ellas. Entienden unos que no le está permitido defenderse y que hay que castigarle si, al hacerlo, da muerte al agresor. La solución no convence ni debe imponerse la pena de muerte, pues, al ser de Derecho Natural la defensa de la propia vida y la salud, las leyes positivas no pueden conculcar este derecho.

Averiguación de oficio.-¿Puede proceder el juez de oficio contra quien ha ofendido o dado muerte al desterrado? Si la ley dispone que el desterrado puede ser ofendido o muerto impunemente, el juez no puede apreciar ni revisar algo cuya licitud se ha declarado ya. Si se establece que el desterrado no sea oído ni que se le haga justicia cuando se le ofende o priva de la vida, 
tampoco cabe actuar de oficio, pues la ley que le impide denunciar una ofensa sufrida, está admitiendo que se le ofenda impunemente.

Ampliación de la impunidad.-Es lícito dar muerte a otro por propia autoridad, si aquel cuya captura se ha acordado resiste al grupo policial y, no habiendo otra oportunidad de apresarle, ese grupo le priva de la vida.

Castigo de la frustración.-De acuerdo con la costumbre general, el que hiere a otro con propósito de matarle y no lo consigue, no sufre la pena correspondiente al homicidio y sí la establecida para las lesiones que su agresión ha originado.

\section{INCESTO}

Personas con las que el incesto se comete.-El incesto se da entre personas ligadas por vínculos de sangre, como sucede cuando el padre tiene trato carnal con su hija o con la hija de la hermana de su mujer, o el hermano tiene dicha relación con su hermana. También es incestuosa la relación que con una monja se mantiene. Si una mujer practica ese contacto con un clérigo consagrado, hay fornicación y no incesto.

Pena del incesto.-El Derecho Civil castiga el incesto con la pena de muerte cuando concurre con otra clase de fornicación, como el adulterio o el estupro. El Derecho Canónico castiga al clérigo incestuoso con la pena de deposición. El incesto cometido al contraer matrimonio se castiga como matrimonio incestuoso. Las penas impuestas a quienes cometen incesto oscilan entre los azotes y la pena de muerte.

Pena de confiscación.-La pena de confiscación de bienes se impone al contrayente de un matrimonio incestuoso, quien pierde la propiedad de aquéllos sin necesidad de que recaiga una sentencia previa o decisión análoga que así lo disponga.

Ampliación al incesto de Derecho Canónico.-Opinan algunos que las disposiciones sobre los matrimonios incestuosos se aplican incluso cuando el incesto existe conforme al Derecho Canónico, aunque no sea tal según el Derecho Civil. El parecer contrario y dominante considera que sólo se dan en el caso de haya incesto conforme al Derecho Civil, al tratarse de la solución más benigna y respaldada por la costumbre como intérprete caracterizada de la ley.

Extensión a otros supuestos.-A diferencia del incesto que surge si contraen matrimonio dos personas ligadas por vínculos de consanguinidad, no es punible el incesto en los casos de matrimonios inválidos o ilícitos, cuales los contraídos con mujer judía, mujer infiel o pariente espiritual. Las penas han de aplicarse equitativamente y no extenderse a casos que no les corresponden.

Pena de excomunión.-Quienes contraen a sabiendas un matrimonio incestuoso, quedan excomulgados de pleno Derecho. 
Matrimonios celebrados bajo condición.-Si dos personas ligadas por vínculos de consanguinidad contraen matrimonio, la opinión minoritaria entiende que la dispensa del Sumo Pontífice no convalida aquél a efectos del incesto. La opinión mayoritaria estima válido el matrimonio contraído y amparado por la dispensa papal.

Exclusión de los esponsales.-Las penas establecidas para los matrimonios incestuosos no se aplican al caso de los esponsales, pues falta el requisito del matrimonio consumado que entonces se requiere.

Excusa fundada en la ignorancia.-Los contrayentes de un matrimonio incestuoso quedan excusados del crimen cuando ignoran el hecho de la consanguinidad prohibida. La pena de pérdida de los bienes no se aplica a quienes, habiendo incurrido en culpa lata, ignoraban la consanguinidad y el obstáculo que representaba.

Conocimiento sobrevenido del incesto.-Si el matrimonio incestuoso se contrae de buena fe y, tras tener noticia de la consanguinidad concurrente, los cónyuges persisten en su relación, no incurren en las penas establecidas por el Derecho Canónico.

Matrimonio entre judíos.-Las penas del incesto no se aplican a los judíos que contraen matrimonio en grado permitido por la ley civil y prohibido por la ley mosaica.

\section{INJURIA}

Modos de comisión de la injuria.-Entre los muchos ejemplos que cabe reseñar, la injuria puede cometerse de hecho o de palabra, golpeando, amenazando o acusando al injuriado de traidor o falsario. Hay una diferencia entre el azote, que produce dolor, y el empellón que no causa dolor alguno.

Ampliación del concepto.-La injuria también se comete y es objeto de acusación cuando, contra la voluntad del propietario de una finca, un extraño la ocupa o entra en ella para capturar piezas de caza.

Injuria causada a la mujer.-La injuria hecha a la mujer se considera hecha al marido. Los estatutos pueden disponer que la injuria causada a un magistrado se entienda también hecha a su cónyuge y establecer el castigo adecuado.

Acciones nacidas de la injuria.-De la injuria nacen acciones respectivamente civil y criminal. Se acciona civilmente cuando se solicita la declaración judicial de haberse producido la injuria. Se acciona criminalmente cuando se pide la imposición de la pena que ha podido corresponder al autor de la acción u omisión injuriosa.

Individualización histórica de la injuria.-No es preceptivo que quien reclama o acusa la comisión de una injuria, identifique el año, el mes y el lugar en que se produjo. 
Valoración del daño causado.-Tampoco hace falta que el libelo de injuria acredite, bajo juramento, la cuantía económica del daño causado por la comisión del delito, pues basta con proponer una valoración aproximada que el juez pondere a su prudente arbitrio.

Carácter de la pena por injurias.-La pena asignada a la comisión de un delito de injuria es una pena arbitraria, cuya imposición exige la consideración judicial de la naturaleza del hecho y de la cualidad de las personas.

¿Declaración de infamia?-El arbitrio judicial puede, en ocasiones, imponer la pena de muerte a quien, condenado por un delito de injurias, es declarado infame. Prima el criterio de que sólo se puede declarar infame al autor de la injuria constitutiva de un crimen atroz, aunque una minoría sostenga que ello cabe también si es módica la injuria.

Prescripción de las acciones. $-\mathrm{La}$ acción criminal por injurias prescribe al cabo de un año, mientras que la civil no está sujeta a prescripción. El plazo se computa con continuidad y sin interrupción alguna.

Remisión tácita.-La conversación o el coloquio mantenido entre el ofensor y el ofendido produce la remisión tácita o implícita de la injuria.

Remisión expresa.-La injuria también se perdona en virtud de remisión expresa. Si la remisión se produce en el fuero de la conciencia, se entiende que el derecho de acusar ha decaído y que quien perdona la injuria, perdona los daños causados más los desembolsos económicos a que ha dado lugar.

Animo de injuriar.-El autor de la injuria no puede alegar en su favor, sin más y para defenderse, que no tenía propósito de injuriar, pues, en la duda, ese designio se presume si el acusado no prueba convincentemente lo contrario.

Protesta de ausencia del ánimo de injuriar.-La acción derivada del delito de injurias no queda sin efecto si el autor hace protesta de que no tiene intención de injuriar y, por ejemplo, acusa al injuriado de mentir para salvar su honor o su respetabilidad. A falta de indicios que demuestren su veracidad, tales alegaciones se estiman injuriosas.

Provocación a la injuria.-Si alguien, tras haber sido provocado por otro, le acusa de mentir, ha de soportar la acusación propia del ejercicio de la acción por injurias, no obstante la existencia e incluso la veracidad de la provocación. Bien es cierto que el autor de la provocación suele recibir un trato caracterizado por la indulgencia del castigo que judicialmente se le impone.

Defensas oponibles.-Generalmente se excusa de la pena por injurias al arrepentido que promete hacer penitencia y arguye que obró movido por la desesperación y la ira. Conforme a la opinión contraria, dicha defensa no puede invocarse como excusa en los delitos cometidos, aunque lleve a imponer una pena más tenue. El calor de la ira no exime de cumplir la penitencia debida por la comisión del delito. 


\section{LESA MAJESTAD}

Modos de comisión del crimen de lesa majestad.-Son muchos los modos de cometer el crimen de lesa majestad. Se citan los ejemplos del súbdito que pacta contra su señor o que ocupa tiránicamente el dominio de la misma ciudad, que lucha contra la propia patria o se alza en armas contra su Soberano, que celebra con los enemigos acuerdos de paz y de amistad, que intenta ocupar, como enemigo, los castillos y las ciudades de su señor, o que destruye con las armas la comunicación entre sus territorios o pone al descubierto sus secretos.

Sujetos pasivos de la lesa majestad.-El crimen de lesa majestad no sólo se comete contra el Papa y el Emperador, sino también contra los reyes, príncipes y ciudades que no reconocen otros poderes superiores al suyo.

Otros sujetos pasivos.-Una opinión minoritaria entiende que el crimen de lesa majestad también se puede cometer contra los reyes, príncipes y ciudades que reconocen una autoridad superior a la suya.

Ofensa a cardenales. - El ofensor de un Cardenal comete un crimen de lesa majestad, pues los cardenales se consideran hermanos del Papa y forman parte de su mismo cuerpo.

Ofensa a consejeros del Príncipe.-El que ofende a un consejero del Príncipe comete crimen de lesa majestad, si actúa por animadversión a uno de ambos. Los consejeros forman parte del cuerpo del Príncipe y ha de entenderse que quien les ofende, ofende al Príncipe si residen junto a él y ocupan su mismo consistorio.

Posición de los no súbditos.-Quien, sin ser súbdito del Príncipe, atenta contra él, no incurre en el crimen de lesa majestad.

Condición de los clérigos.-El clérigo nacido en tierra sometida al soberano laico, no se considera súbdito del mismo ni se admite que pueda incurrir en un delito de lesa majestad. Los clérigos deben evitar involucrarse en estos problemas, pues, pese a la citada excusa, los príncipes seculares no suelen respetarla.

Pena del crimen de lesa majestad.-Este crimen se castiga con la pena de muerte y la exhibición del cadáver del ejecutado en los lugares principales de las ciudades o fortalezas en que haya delinquido.

Confiscación de bienes.-A diferencia de las normas del Derecho común, la comisión del crimen de lesa majestad produce la pérdida inmediata del dominio y la administración de los bienes del reo, aunque no haya recaído sentencia declarativa de la existencia del delito. Las penas impuestas a los hijos de los autores de un delito de lesa majestad deben restringirse en lo posible, pues atenta contra las reglas de Derecho el castigar a una persona por el delito que otra ha podido cometer. Esas penas nunca se aplican a las hijas del condenado.

Aplicación de la pena a los hijos naturales.-El criterio también rige en provecho de los hijos naturales. 
Aplicación de la pena a los hijos predelictuales.-Sostienen unos que las penas por el crimen de lesa majestad se aplican incluso a los hijos nacidos antes de que su padre delinquiese. La opinión contraria excluye de la sanción penal a los hijos nacidos o concebidos antes de dicha comisión. Este segundo parecer resulta más moderado y benévolo.

Aplicación de la pena a los sobrinos.-La extensión de la pena a los hijos del autor de un delito de lesa majestad también alcanza a los sobrinos hasta el segundo grado de la descendencia, si se trata de varones, y hasta el primer grado en el caso de las mujeres. La ampliación tiene lugar aunque la condenada sea una mujer, pese a lo inusitado de esta variante de autoría y la interdicción de aplicar extensivamente las normas penales.

Limitaciones de la extensión de la pena.-Las penas estatutarias contra los hijos sólo se aplican si el crimen de lesa majestad tiene por objeto al Emperador o a la República Romana.

Punibilidad de la intención.-Al contrario del común de los delitos en que la intención queda impune si no le acompaña el resultado, el delito de lesa majestad se castiga siempre que conste el propósito de cometerle, aunque no se logre el efecto querido. Incluso se sanciona el conocimiento adquirido por quienes no revelan lo que se convino para delinquir.

Extinción por muerte-Aunque los crímenes se extinguen comúnmente por muerte de su autor, el crimen de lesa majestad puede dar lugar a la apertura del procedimiento, al enjuiciamiento consiguiente y a la condena de la memoria de aquél. Esta especialidad se limita al crimen de lesa majestad contra el Soberano o la República Romana, pues el cometido contra otros soberanos inferiores o ciudades se extingue con el fallecimiento. El derecho a acusar el delito y eliminar la memoria del difunto prescribe a los cinco años.

Muerte del rebelde.-Se afirma que el rebelde puede ser muerto impunemente, si se demuestra luego su cualidad de tal. La opinión es peligrosa y, antes de dicha ejecución, se aconseja contar con el asentimiento y voluntad del Príncipe o haber sorprendido al rebelde en el acto de delinquir. El homicida queda en libertad tan pronto como conste la rebeldía de la persona a la que ha dado muerte.

Enjuiciamiento del ausente.-Aunque se prohíbe condenar al ausente por la comisión de cualquier crimen, se le puede acusar del crimen de lesa majestad y, si ha incurrido en contumacia, condenarle a muerte.

\section{JUEGO}

Prohibición del juego.-Se ha llegado a la conclusión general de que la práctica del juego se encuentra prohibida.

Juegos de ingenio y fortuna.-Esta conclusión no sólo se aplica a los juegos cuyo resultado depende exclusivamente de la suerte, sino también a 
los que combinan el ingenio y la fortuna, como sucede con los juegos de mesa y de cartas que no escapan a la prohibición. El juego se autoriza cuando su resultado depende exclusivamente del ingenio, de lo cual se infiere que esta variante es lícita en Derecho. La costumbre ha dejado sin efecto la prohibición de apostar más de un áureo en los juegos permitidos.

Autorización a los clérigos.-Está permitido a los clérigos jugar al talego.

Autorización a los laicos.-Los laicos pueden organizar torneos y entretenimientos en los que nada queda al albedrío de la suerte, porque sólo intervienen la agilidad corporal y el ingenio de los participantes.

Licitud de las apuestas.-Son lícitos los llamamientos a la suerte que el vulgo denomina apuestas.

Pena de los juegos prohibidos.-El Derecho Civil no establece una pena concreta para los juegos prohibidos, si bien se admite que quienes los practican sean condenados a una pena extraordinaria en que el arbitrio judicial pondere los hechos y la calidad de las personas.

Restitución de lo ganado en juego.-El vencedor en los juegos de azar prohibidos no está obligado a restituir los lucros obtenidos, siempre que no haya cometido fraude. También se apunta la posibilidad de destinar esas cantidades al socorro de los pobres.

Derecho a repetir.-Aunque el Derecho prohíbe que quien ha procurado dinero para el juego repita contra el prestatario, la práctica en contrario admite la repetición que, entre clérigos y laicos, ha introducido la costumbre.

Transacción en el juego.-No es ilícita la transacción en el acto del juego o con ocasión del mismo.

\section{PARRICIDIO}

Comisión del parricidio.-Comete parricidio el que causa la muerte de su padre o de su propio hijo.

Muerte del padre natural.-El que da muerte a su padre natural es considerado parricida y castigado con las penas que la ley o el estatuto atribuyen a este crimen, ya que se atiende a la sustancia y no a la calidad o naturaleza de la filiación.

Muerte de los descendientes.-Aunque el parricidio parece limitarse al caso de la muerte causada al padre o al hijo, la pena fijada para los parricidas se extiende a los que matan a alguno de sus ascendientes o descendientes.

Muerte de los parientes colaterales.-La misma pena ha de aplicarse al que mate a su hermana, a su hermano o a cualquier otro pariente colateral dentro del quinto grado.

Pena del parricidio.-Habiendo caído en desuso la pena consistente en arrojar al parricida al mar o al río más cercano, se le aplica, como a cualquier homicida, la pena de decapitación. Esta prevalece sobre otras modalidades más brutales y no deniega al parricida la sepultura eclesiástica. 


\section{PERJURIO}

Comisión del perjurio.-El perjurio consiste en la mentira producida bajo juramento.

Pena del perjurio.-El perjurio lleva consigo la pena de infamia, cuya imposición requiere que el delito atente contra la promesa y contra el juramento, pero que no cabe si se da sólo contra el juramento. Si, bajo el denominado juramento aseverativo, se afirma algo falso de pasado o de presente, no ha lugar a la nota de infamia que procede cuando, bajo el llamado juramento promisorio, se promete dar, hacer u omitir algo que en el futuro no se cumple.

Perjurio de clérigos.-El clérigo que incurre en perjurio puede ser privado de la dignidad que ha obtenido, aunque la privación no se produce de pleno Derecho y ha de constar en la sentencia de condena. Automáticamente pierde el beneficio que, en su caso, se le haya otorgado.

Acciones del perjuro.-El perjuro queda incapacitado para ejercitar cualquier clase de acciones.

Excusa del perjurio.-El perjuro queda excusado de la pena, si consta que el delito se cometió sin dolo.

Dificultades de expresión.-El perjurio se excusa si su comisión se ha debido a dificultades de expresión.

Excusa por ausencia de daño.-El perjurio se excusa probando que la declaración del perjuro no ha perjudicado ni puede perjudicar a nadie. La excusa se limita al fuero contencioso, pues el castigo sólo corresponde a DIOS en el fuero del alma.

Casos de impunidad.-Hay casos en que el perjurio no puede castigarse judicialmente, si lo cometen los reos acusados del delito o interrogados sobre las circunstancias de su comisión.

Juramento deferido.-Cuando una parte presta juramento en juicio a solicitud de la otra, no puede ser judicialmente acusada de perjurio, pues el castigo del mismo sólo corresponde a DIOS.

\section{RAPTO}

Comisión del crimen.-El crimen de rapto se comete cuando, con ánimo libidinoso, el varón se apodera de una mujer y la traslada de un lugar a otro. Sin esa traslación no existe rapto. Cuando, sin traslación, el varón viola a la mujer, tampoco hay rapto, pero sí un acto delictivo castigado con la pena de muerte.

Pena del rapto.-Una Constitución justinianea establece la pena de muerte $\mathrm{y}$ otras penas graves para los raptores.

Consentimiento de la mujer.-El rapto se castiga aunque la mujer lo consienta antes o después de haberse cometido. Se consideran raptores los 
que, sin violencia y con propósito libidinoso, usan de engaños y de halagos para trasladar a las jóvenes de un lugar a otro.

Ausencia de contacto carnal.-Mientras unos sostienen que el rapto se comete aunque no haya habido contacto carnal, la mayoría comparte la opinión contraria y se opone al castigo del raptor. Se distingue también si la ausencia de contacto carnal se ha debido al desistimiento del autor o a las dificultades con que ha tropezado para delinquir.

Condición de la mujer raptada.-Aunque excepcionalmente la pena del rapto se aplicó a los raptores de mujeres públicas, los raptores de mujeres deshonestas sólo son castigadas con una pena arbitraria.

Mujer raptora.-Aunque excepcionalmente la pena del rapto se aplicó también a la mujer, se sostiene que ésta no comete rapto respecto del varón, pues no concurren las circunstancias de escándalo que se dan en el caso contrario. La mujer que no es condenada a pena de muerte, sufre una pena grave que fija el arbitrio judicial según la naturaleza del hecho y la cualidad de las personas. No se consideran raptores los militares y los recaudadores que, tras adueñarse de los niños, los retienen contra la voluntad de los padres deudores de tributos.

Matrimonio del raptor con la mujer raptada.-Mientras que el Derecho Civil veda el matrimonio del raptor con la mujer raptada, el Derecho Canónico lo autoriza. La pena de confiscación de bienes se aplica indistintamente a los raptores que contraigan matrimonio civil o canónico con la mujer raptada.

Derecho de asilo.-El raptor no goza de inmunidad aunque se refugie en una Iglesia.

\section{SACRILEGIO}

Comisión del sacrilegio.-Según el Derecho Civil, la comisión del sacrilegio exige que la cosa hurtada sea sagrada y que se la sustraiga del lugar sagrado en que se encuentra. El Derecho Canónico sólo requiere que concurra una u otra de ambas condiciones.

Sacrilegio de la mujer.-Comete sacrilegio la mujer que mantiene contacto carnal con un presbítero.

Carácter del sacrilegio.-El crimen de sacrilegio puede ser secular o eclesiástico. El Derecho Civil castiga el sacrilegio con pena extraordinaria que toma en consideración la cualidad de la persona. El sexo siempre es, sin embargo, capital. La costumbre admite que, cualquiera que sea la modalidad del sacrilegio, el delito se castigue con pena de muerte. Hay circunstancias que agravan el sacrilegio y justifican la pena de muerte, como el del primer hurto perpetrado por quien, de noche, violenta la puerta de una Iglesia y se adueña del cáliz que contiene las especies eucarísticas. Las cosas y la calidad de las personas suelen tenerse en cuenta para condenar a la pena del último suplicio o imponer una pena extraordinaria. 
Texto sobre el sacrilegio.-Cuando la norma estatutaria ha sido promulgada por laicos, se entiende que atañe al sacrilegio castigado por el Derecho Civil. Si ha sido dada por eclesiásticos, se la considera relativa al sacrilegio de Derecho Canónico.

\section{SIMONÍA}

Significado de la simonía.-La simonía consiste en la voluntad deliberada, el deseo o el vicio de comprar o vender algo espiritual o relacionado con ello. Se habla de comprar o vender, porque la verdadera simonía no se comete si no media una promesa o exacción. No hay simonía cuando se ruega o concede algo de modo gracioso, salvo si se pretende que un resultado notoriamente indigno prevalezca sobre otro de dignidad superior.

Retribución por la administración de sacramentos.-No existe simonía cuando se percibe algo para remunerar el trabajo consistente en la administración de un sacramento, siempre y cuando el acuerdo no afecte al destino de alguna cosa espiritual y sólo implique una módica compensación.

Concesión de licencia.-Quien recibe dinero por la concesión de una licencia para enseñar, no incurre en simonía, aunque se dice que comete cuasisimonía.

Otorgamiento de un oficio público.-Es lícito el ofrecimiento de una suma para obtener un oficio público, siempre y cuando se trate de un oficio temporal que aproveche a quien le necesita. Si el ofrecimiento se hace al Soberano, decae el ámbito del crimen, mientras que, si se dirige a otras personas, incurren en la pena de infamia los que le conceden y los que le solicitaron y obtuvieron.

Comisión de simonía por el Papa.-Se afirma que el Papa comete simonía cuando recibe algo a cambio de la colación de algún beneficio. En contra, se sostiene que la simonía sólo está prohibida por el Derecho Positivo y no puede cometerse por el Papa que se halla por encima de todo Derecho. Si el Papa vende algún sacramento, incurre en la simonía prohibida por el Derecho Divino.

Ambito de la simonía.-La simonía no puede perseguirse en la Curia Romana mientras el actual Pontífice la siga tolerando. Los simoníacos deben obrar con tiento y recordar que las Bulas y las Constituciones de los Sumos Pontífices han execrado este crimen con máxima dureza.

Naturaleza de la simonía.-El crimen de simonía es exclusivamente eclesiástico, de modo que los jueces seculares no pueden conocer del mismo ni ingerirse en su procedimiento.

Pena de la simonía.-El simoníaco notorio queda suspendido de pleno Derecho en el desempeño de su oficio.

Pérdida de los beneficios.-Si bien el clérigo simoniaco queda privado de los beneficios que pueda ostentar, no dan lugar a dicha privación las conven- 
ciones y los pactos ilícitos que, aunque lo parezcan, no constituyan una pura y verdadera simonía.

Crimen exceptuado.-La simonía se cuenta entre los crímenes de excepción, aunque sólo se cometa en beneficio propio.

Prueba de la simonía.-Mientras que, en el común de las causas criminales, se requieren pruebas más claras que la luz del mediodía, basta que, tratándose de la simonía, concurran conjeturas e indicios cuya constancia lleve al convencimiento de que el reo ha sido el autor de ese crimen.

\section{SODOMÍA}

Reprobación de la sodomía.-La sodomía o coito contra la naturaleza es un vicio nefando y detestable por encima de todos los demás.

Comisión con mujer.-Existe sodomía cuando el coito contrario a la naturaleza se realiza con una mujer.

Carácter de la sodomía.-De este delito, que es de fuero común, conocen indistintamente los jueces eclesiásticos y los jueces seculares.

Pena de la sodomía.-El Derecho Civil castiga con la pena de muerte a los agentes y pacientes de la sodomía. La costumbre ha dispuesto que, en vez de ser decapitado, el sodomita condenado arda en la hoguera.

Sodomía de los clérigos.-Aunque un clérigo cuide de ocultar su sodomía e incluso haga penitencia, queda suspenso en el sacramento del orden e incurre en una irregularidad que ni el Romano Pontífice puede subsanar.

Destino de los bienes.-El sodomita condenado pierde de pleno Derecho la propiedad de sus bienes, aunque esta pena de confiscación haya dejado de aplicarse en algunos territorios.

Separación de los cónyuges.-Sostienen algunos que la condena por sodomía sólo da lugar a la separación de los cónyuges si el marido, que cohabita con otro varón, ha intentado sodomizar a la mujer. Impera la opinión de que, si el adulterio del varón concede a la mujer el derecho a la separación de lecho, con mayor razón procede esta medida en el caso de la sodomía, que es un crimen más grave y del que se resiente la solidez del matrimonio.

Castigo de la intencionalidad.-El carácter atrocísimo de la sodomía determina que, según la costumbre general, se castigue la intencionalidad, aunque sus efectos no hayan llegado a producirse. Criterio que el Senado desatiende cuando declara que, en lugar de la pena de muerte, ha de imponerse una pena extraordinaria.

\section{ESTUPRO}

Modos de comisión del estupro.-El estupro puede cometerse con mujeres vírgenes, con mujeres viudas y con niños. 
Prueba del estupro.-El estupro no puede probarse con testigos domésticos cuyas declaraciones sólo tienen valor de indicio o conjetura.

Pena del estupro.-El Derecho Canónico castiga con la pena de deposición al clérigo que ha cometido estupro con una mujer virgen. El laico que ha cometido estupro con una mujer virgen está obligado a dotarla y a contraer matrimonio con ella, si la misma o su padre lo consienten, ya que, si no acceden, la obligación se reduce a la dote. Si el estuprador incumple esta reparación, es flagelado y recluido en un monasterio donde debe hacer penitencia. No faltan ejemplos en que, ante la fragilidad de la persona estuprada, se acumulan las dos obligaciones de tomarla en matrimonio y dotarla decorosamente. La pena de muerte sólo se impone si el estupro se ha cometido con violencia.

Presunción de virginidad.-Aunque el autor sostenga que la mujer no era virgen al tiempo de yacer con ella, la virginidad se presume en caso de duda e incumbe al estuprador probar su afirmación. No consta que se haya condenado a nadie por cometer estupro con una mujer viuda.

Pérdida de la dote.-La opinión se divide en torno a la cuestión de si la viuda víctima del estupro pierde la dote al contraer nuevo matrimonio. El parecer más autorizado adopta un criterio de benignidad y entiende que es reprobable mantener esta postura, aunque el estupro se cometa durante el transcurso del año de luto.

\section{CONCLUSIONES}

Ante la interposición de elementos heterogéneos, lo espinoso de análisis convincentes, las tentativas de ordenación sistemática de las fuentes y la plétora de opiniones, la contribución de los prácticos -singularizada por sus novedosos objetivos y su empeño en superar los caminos trillados del Derecho Penal- culminó la tarea de enorme calidad que revelan el saber y la comprensión de Julio Claro de Alejandria.

De la recepción del Derecho Romano formaba parte la edificación de un Derecho Penal formado por los Estatutos de las ciudades libres, plasmado y difundido en los cuerpos de doctrina comunes o afines que suscitaba el planteamiento de problemas debatidos en ciertas hipótesis y sujetos al ejercicio de la justicia punitiva. Había comenzado con la fase inicial de los glosadores, cuyas respuestas incluyeron buena parte de las soluciones generales que interpretaban la legislación justinianea, dominada -ya entonces-por los signos primarios de los tiempos. Los postglosadores fundaron su pensamiento en el recio andamiaje de los comentaristas de la glosa y tomaron su creatividad central de las tesis de los comentaristas precedentes, mostrando sus intensos deseos de recuperación. No se contentaron con operar sobre el Derecho justinianeo y propagar las perspectivas de su estudio a los ámbitos de las costumbres generales, de los usos y Derechos locales, y de los usos y costumbres 
de los Tribunales de justicia. A esta segunda fase siguieron las incursiones de los prácticos en que, con diferencia, fue primera figura Julio Claro de Alejandría y cuyas aportaciones -enriquecedoras y atractivas- continuaron hasta el fin de la etapa de los prácticos tardíos. Su actitud combativa y creadora-precursora y modelo del ejercicio del derecho de resistencia- nunca decayó en el inquebrantable propósito de alzarse contra la arbitrariedad, las demasías y la desigualdad de las prácticas punitivas reprobables. De esa tenacidad se alimentaron -andando el tiempo- la emergencia del pensamiento ilustrado y los cambios de rumbo debidos a las conmociones y emociones del Siglo de las Luces.

\section{BIBLIOGRAFÍA DE ORIENTACIÓN}

CALISSE, E. «Svoglimento storico del Dirito penale in Italia dalle invasione barbariche a la reforma del secolo XVIII», en Enciclopedia de Pessina, Milán, 1905, pp. 255 y sigs.

Claro de Alejandría, J., Receptae sententiae y Practica civilis et criminalis, referidas ut supra.

Garibaldi, A., «Los prácticos en la elaboración del Derecho Penal», Revista del Centro de Estudiantes de Derecho, Montevideo, n. ${ }^{\circ} 77$, pp. 180 y sigs.

Jimenez De Asua, L., Tratado de Derecho Penal. Buenos Aires, vol. 1, t.1. Ed. Losada, 1956; «Los prácticos con especial consideración de los españoles», en Revista jurídica de Córdoba (Argentina), n. ${ }^{\circ}$ 3, 1947, pp. 349 y sigs.

ZorrILLA, M. M., «El Derecho Penal en la Práctica italiana del siglo XVI», Anuario de Derecho penal y Ciencias penales, t. 14, 1961, pp. 111-125; «Ideas penales de Julio Claro de Alejandria», Estudios de Deusto, vol. XIII, 1965, pp. 757-774.

TITLE: Generalization of the practical thinking about the specific samples of criminality.

RESUMEN: La ordenación del pensamiento de los penalistas occidentales constituye una incidencia del fenómeno receptor del Derecho Civil y el Derecho canónico. Entre sus representantes más egregios figura Julio Claro de Alejandría, perteneciente a la escuela de la madurez de los prácticos e introductora en España de una etapa de reflexión y progreso. Una fase superadora de los adelantos de los comentaristas iniciales de las fuentes romanas y del esfuerzo subsiguiente de los postglosadores. El análisis alfabético de los delitos, al que preceden algunas consideraciones generales y una clasificación, comprende el adulterio, el asesinato, la falsificación en sentido amplio, la fornicación, el incesto, la injuria, el crimen de lesa majestad, el juego, el parricidio, el perjurio, el rapto, el sacrilegio, la simonía, la sodomía y el estupro. Las ediciones manejadas han dado lugar a que, no obstante la densidad descriptiva del texto latino y la detención que requiere extraer del mismo ciertas formulaciones $y$ principios, se adquiera una noticia razonable de cómo-atenta a los flujos de la recepción-la obra de Julio Claro de Alejandria señala el punto de 
inflexión entre la atención al cuadro de los elementos históricamente significativos y las adiciones doctrinales que provocó su advenimiento.

PALABRAS CLAVE: recepción, tipos delictivos, punto de inflexión, periodo de madurez, Escuela de los Prácticos.

ABSTRACT: The ordination of the western criminal law shows a detail in the phenomene of the reception of the civil and canonical law. One of the most dense latin versions is due to Julio Claro de Alejandria, pertaining to the Practical School, introducer in Spain of a ripe and reflexive period. He surpasses the main advances of the roman sources and the effort performed by the gloss. After the general consideration of the criminal models, the specific analisis includes the tipes of adulterium, assasinium, blasphemia, falsum, fornicatio, incestus, herejia, lesa majestas, parricidium, ludus, perjurium, raptus, sacrilegium, simonía, sodomía and estuprum. The editions used and the motley latin version show the inflexion point between the attention to the fusion of the significant events of the History and the scientific reflections due to its appearance.

KEYWORDS: reception, criminal types, inflexion point, ripe and reflexive period, Practical School. 